\title{
MINERAL RESOURCE POTENTIAL OF THE ANACONDA-PINTLAR WILDERNESS AND CONTIGUOUS ROADLESS AREA, GRANITE, DEER LODGE, BEAVERHEAD, AND RAVALLI COUNTIES, MONTANA
}

By

\author{
James E. Elliott, Chester A. Wallace, J. Michael O'Neill, \\ William F. Hanna, Lawrence C. Rowan, Donald B. Segal, David R. Zimbelman, \\ and Robert C. Pearson, U.S. Geological Survey \\ and
}

Terry J. Close, Francis E. Federspiel, J. Douglas Causey, Spencee L. Willett, Richard W. Morris, and James R. Huffsmith, U.S. Bureau of Mines

\section{STUDIES RELATED TO WILDERNESS}

Under the provisions of the Wilderness Act (Public Law 88-577, September 3, 1964) and related acts, the U.S. Geological Survey and the U.S. Bureau of Mines have been conducting mineral surveys of wilderness and primitive areas. Areas officially designated as "wilderness," "wild," or "canoe" when the act was passed were incorporated into the National Wilderness Preservation System and some of them are presently being studied. The act provided that areas under consideration for wilderness designation should be studied for suitability for incorporation into the Wilderness System. The mineral surveys constitute one aspect of the suitability studies. The act directs that the results of such surveys are to be made available to the public and be submitted to the President and the Congress. This report discusses the results of a mineral survey of the Anaconda-Pintlar Wilderness and contiguous roadless area, 1-001B, Beaverhead, Bitterroot, and Deerlodge National Forests, Granite, Deer Lodge, Beaverhead, and Ravalli Counties, Mont. The Anaconda-Pintlar Wilderness was established by Public Law 88-577, 1964. The contiguous roadless area was recommended for wilderness designation during the Second Roadless Area Review and Evaluation (RARE II) by the U.S. Forest Service, January 1979.

\section{SUMMARY STATEMENT}

A mineral survey of the 250-sq-mi (160,000-acre) Anaconda-Pintlar Wilderness in southwestern Montana was conducted by the U.S. Bureau of Mines from 1978 to 1980 and by the U.S. Geological Survey from 1980 to 1982 . Results of this survey indicate that the wilderness contains seven areas that have moderate and moderate to high potential for resources of silver, copper, molybdenum, lead, tungsten, tin, gold, and zinc, in various deposit types. Two of these areas, the Senate mine-Kelly Lake and Warren Peak areas, have identified resources of silver, copper, and lead in five deposits totaling 180,300 tons of mineralized rock. In addition, the Senate mineKelly Lake area has moderate to high potential for undiscovered resources of silver, copper, lead, and gold in mesothermal vein, replacement, and placer deposits, and the Warren Peak area has moderate to high potential for undiscovered resources of silver, lead, copper, zinc, and molybdenum in mesothermal vein and porphyry (or stockwork) deposits. The Beaverhead Mountain area has moderate potential for undiscovered resources of molybdenum, copper, silver, tungsten, and tin in porphyry (or stockwork), mesothermal vein, and skarn deposits. The Mount Howe-Mount Evans area has moderate potential for undiscovered resources of molybdenum and copper in porphyry (or stockwork) and mesothermal vein deposits. The Lower Seymour Lake area has moderate potential for undiscovered resources of molybdenum, silver, and tungsten in porphyry (or stockwork) deposits. There is moderate potential for the occurrence of undiscovered resources of silver, tungsten, and copper in mesothermal vein and replacement deposits in the One Hundred Acre Meadow area and of gold in placer deposits in the Copper Creek area. Other resources that may be present in the study area, such as sand, gravel, stone, and other nonmetallic commodities, are more readily accessible in areas outside the wilderness and contiguous roadless area. On the basis of the nature of the geologic terrain (that is, lack of young volcanic rocks, hot springs, and coal-bearing formations, and evidence of past heating to high temperatures as indicated by abundant plutonic and metamorphic rocks), geothermal, coal, oil, and natural gas resources are not to be expected. 


\section{INTRODUCTION}

\section{Location and geography}

The Anaconda-Pintlar Wilderness (fig. 1) covers about $250 \mathrm{sq} \mathrm{mi}(160,000$ acres $)$ in southwestern Montana and includes parts of Granite, Deer Lodge, Beaverhead, and Ravalli Counties. In addition to the wilderness, the area covered in this report, which will be referred to as the study area, includes a roadless area of about $10 \mathrm{sq} \mathrm{mi} \mathrm{(RARE} \mathrm{II} \mathrm{no.} \mathrm{1-001B)} \mathrm{contiguous}$ to the south end of the wilderness. The RARE II area has been recommended by the U.S. Forest Service for addition to the wilderness. The study area also includes a marginal belt approximately 1-2 mi wide outside the wilderness and roadless area boundaries. The study area includes parts of the Beaverhead, Bitterroot, and Deerlodge National Forests.

The northeastern end of the study area is about $13 \mathrm{mi}$ southwest of Anaconda, and the southwestern end of the study area is about $20 \mathrm{mi}$ north of Wisdom; Philipsburg is about $17 \mathrm{mi}$ north of the area. The boundary of the wilderness is accessible by dirt and gravel roads that connect with U.S. Highways $10 \mathrm{~A}$ and 93 and State Highways 38 and 43. Many of the numerous trails through the study area are well maintained and suitable for horse packing and riding as well as foot travel.

The study area lies along the crest and slopes of the rugged Anaconda Range (fig. 1); this northeasttrending range terminates near Anaconda, to the northeast, and, to the southwest, against the northwest-trending Bitterroot Range. The crest of the Anaconda Range is the Continental Divide. The southeast side of the range is drained by tributaries of the Big Hole River, a major drainage in the headwaters of the Missouri River. The west, northwest, and north sides are drained by tributaries of the Clark Fork, a part of the Columbia River drainage system.

The area is one of rugged relief; elevations range from a low of 5,400 ft in the valley of the East Fork Bitterroot River to $10,793 \mathrm{ft}$ on West Goat Peak, the highest point in the area. Nine peaks are above 10,000 ft, and many peaks and ridges are between 9,000 and $10,000 \mathrm{ft}$. Streams that drain the range originate in glacial cirques that commonly contain alpine lakes and drain to the north, south, and west along linear to slightly curved valleys carved by glacial ice.

\section{Previous studies}

Few published reports describe rocks or mineral resources in the study area. The most comprehensive report on the geology and mineral deposits of the region is by Emmons and Calkins (1913); their work covers part of the study area north of $46^{\circ} 00^{\prime}$ latitude and east of $113^{\circ} 30^{\prime}$ longitude. A geologic $\mathrm{m}$ ap and a description of geology and structure for this part of the study area was published in 1956 by Poulter. Theses and reports by Flood $(1974,1975)$ and Wiswall (1976, 1977) describe areas in the central part of the study area. Pederson (1976) mapped and studied the mineral deposits of an area that includes the upper drainage basin of the Middle Fork Rock Creek. Mines and prospects in the Middle Fork Rock Creek and East Fork Rock Creek drainage areas have been described in unpublished reports by Corry (1920), Oster (1944), and Stentz (1975).

\section{Present studies}

Studies of the mineral resource potential of the Anaconda-Pintlar Wilderness and contiguous roadless area consisted of geologic mapping and the application of remote sensing techniques, during 1981 and 1982 , and geochemical sampling and geophysical surveying during 1980 and 1981, all by the U.S. Geological Survey; the U.S. Bureau of Mines investigated mines and prospects during 1978, 1979, and 1980 (Close and others, 1982).

\section{GEOLOGY, REMOTE SENSING, GEOPHYSICS, AND GEOCHEMISTRY}

\section{Geology and structure}

Rocks exposed in the study area are mostly sedimentary and igneous, ranging in age from Proterozoic to Tertiary. Proterozoic and Paleozoic sedimentary rocks are commonly metamorphosed, especially at or near intrusive contacts. The core of the Anaconda Range is composed of two major rock types: (1) sedimentary rocks of the Proterozoic Y Belt Supergroup and Paleozoic sedimentary rocks, which are exposed along the northwestern side of the range north of the East Fork Bitterroot River; and (2) Tertiary and Cretaceous granodioritic to granitic plutonic rocks that are exposed over much of the southwestern part of the study area and southeastern side of the range (fig. 2). The sedimentary rocks are in a series of thrust plates that were faulted into their present configuration during the Cretaceous. These rocks were subsequently intruded by plutons of Late Cretaceous and early Tertiary age. Uplift and erosion of the range occurred in Tertiary time during which Eocene through Pliocene sediments were deposited both north and south of the range into adjacent intermontane basins. The range was apparently raised to its present elevation in late Tertiary and Quaternary time along northeast-trending, high-angle faults that can be traced along the southeast margin of the range. The range, strongly glaciated in Pleistocene time, contains many cirques, tarns, and ice-carved valleys.

\section{Proterozoic rocks}

Belt Supergroup (Proterozoic Y) rocks are well exposed in the study area; these rocks consist mainly of middle Belt carbonate rocks of the Helena Formation and younger clastic rocks of the overlying Missoula Group. Most of the carbonate rocks belong to the Helena Formation; the Wallace Formation, the western stratigraphic equivalent of the Helena Formation, is exposed only as thrust slices west of the Middle Fork Rock Creek. The Helena and Wallace Formations grade upward into the Snowslip Formation of the Missoula Group. Thrust faults separate the Snowslip Formation from the younger Mount Shields Formation. The Bonner Quartzite rests on the Mount Shields Formation. The youngest unit of the Missoula Group exposed in the study area is the Garnet Range 


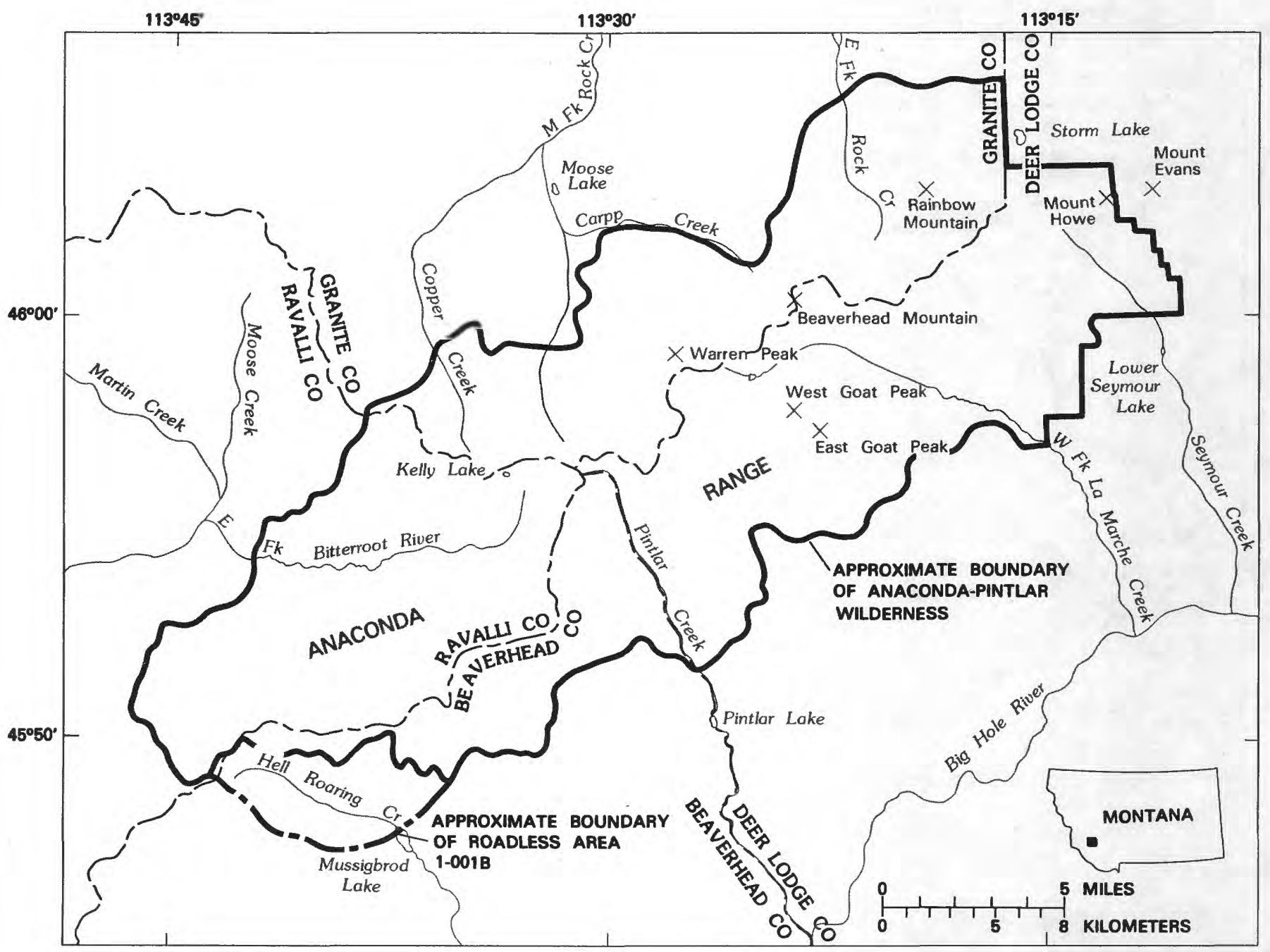

Figure 1.--Index map showing location of the Anaconda-Pintlar Wilderness and contiguous roadless area, Granite, Deer Lodge, Beaverhead, and Ravalli Counties, Mont. 


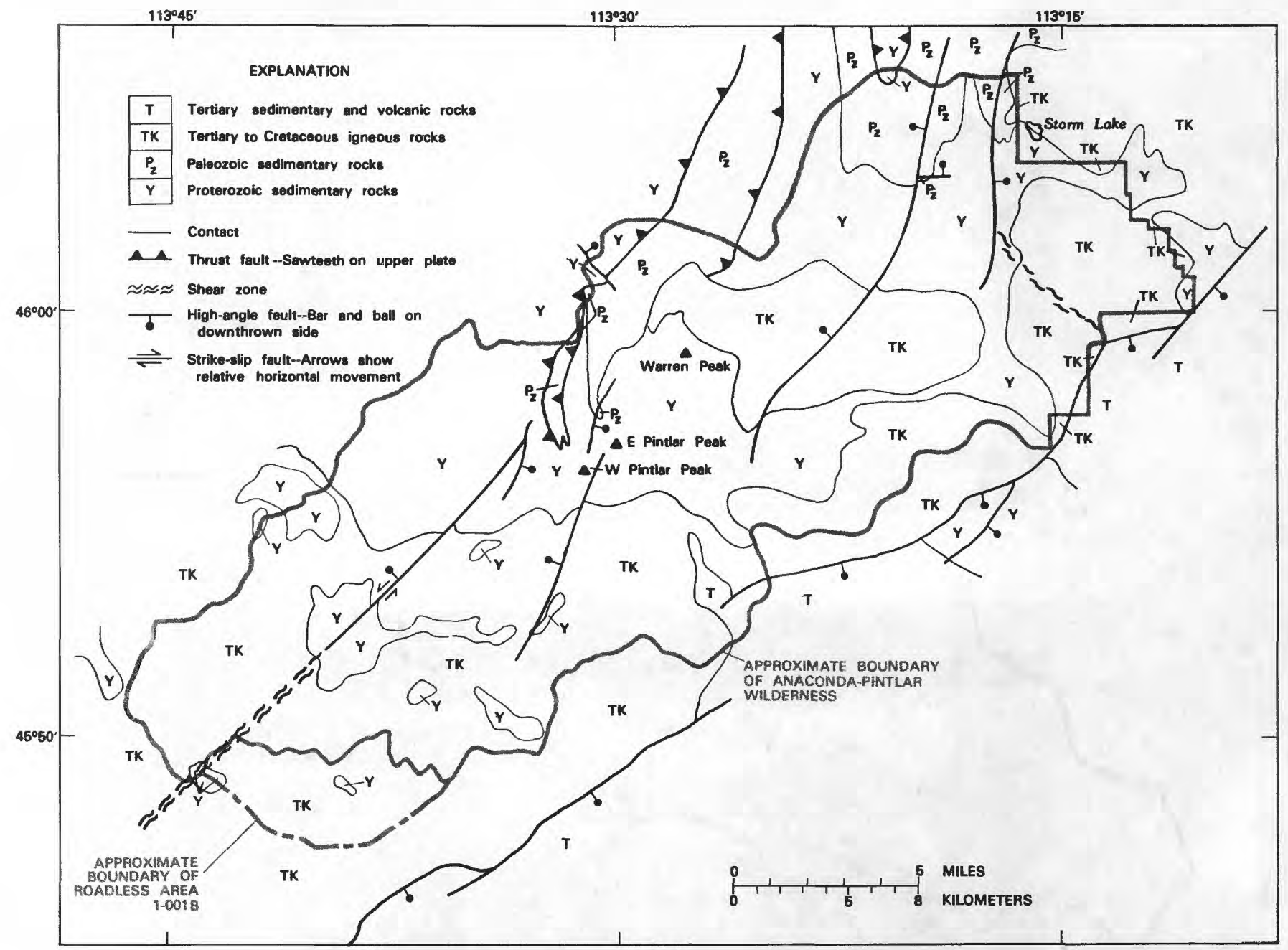

Figure 2.--Simplified geology of the Anaconda-Pintlar Wilderness, contiguous roadless area, and vicinity. 
Formation which is separated from all underlying Belt rocks by thrust faults.

\section{Phanerozoic rocks and deposits}

The Paleozoic sedimentary rocks exposed in the study area are typical of the Paleozoic succession found in west-central Montana and represent sediments deposited in the shallow marine environment of the Cordilleran miogeosyncline. The Cambrian Flathead Formation lies unconformably on the Garnet Range Form ation and grades upward into the Cambrian Silver Hill Formation. Overlying this unit are Upper and Middle Cambrian rocks of the Hasmark Dolomite and the overlying Upper Cambrian Red Lion Formation. A major unconformity separates the Cambrian rocks from the Devonian Maywood Formation. These rocks are overlain by a thick succession of carbonate rocks that includes the Devonian Jefferson Formation through the Mississippian Madison Group. The overlying Pennsylivanian Amsden Formation is overlain by orthoquartzite of the Pennsylvanian Quadrant Formation.

Tertiary sedimentary rocks are not common in the study area, but some are present on the southeast side of the study area, mostly outside the wilderness. These basin-fill deposits of the Big Hole basin have been juxtaposed with plutonic and Proterozoic sedimentary rocks by high-angle faults that mark much of the southeast margin of the Anaconda Range. Minor volcaniclastic deposits and felsic volcanic flows are locally interbedded with these rocks in the Big Hole basin. Tertiary deposits present within the Anaconda Range consist of a thin gravel veneer that locally covers high, flat-topped ridges.

Quaternary deposits are mainly of glacial origin and are present as thin deposits on valley floors and walls in the upper reaches of all drainage basins. Bouldery deposits marked by terminal, recessional, and associated lateral moraines are the most abundant glacial deposits and are well exposed in the lower parts of all valleys. The most recent deposits in the study area consist of alluvial stream gravels and some recent, abundant, and rather large landslide deposits that occur in loosely consolidated basin-fill and till deposits in the southeastern part of the area.

\section{Igneous rocks}

About half of the rocks exposed in the study area are plutonic rocks related in space and time to igneous activity of the Idaho and Boulder batholiths and other batholiths of the region. These rocks were emplaced in Late Cretaceous and Paleocene time. The oldest rocks were intruded between 75 and $65 \mathrm{~m} . y$. ago and consist of stock-sized bodies of generally equigranular, foliated granodiorite and tonalite, monzogranite, and quartz dioxite. Late Cretaceous to early Tertiary plutonic rocks in the study area are commonly porphyritic and include stocks of two-mica leucomonzogranite and granodiorite, a batholith of twomica granodiorite, and dikes of granodiorite and dacite porphyry. The youngest intrusive rocks consist of northeast-trending swarms of Tertiary rhyolitic to rhyodacitic dikes whose emplacement was controlled by major northeast-trending faults and shear zones that cross the Anaconda Range.

The intrusion of plutonic rocks in the southwestern part of the study area was commonly accompanied by high-grade regional metamorphism of the adjacent wall rocks that are now preserved as strongly folded, migmatitic, sillimanite-bearing quartzofeldspathic gneiss, and calc-silicate rock. Sedimentary rocks adjacent to plutons and numerous siliceous dikes and sills in the central and northeastern parts of the study area generally show only contact metamorphic effects.

\section{Structure}

Sedimentary rocks in the study area occur in a series of stacked thrust plates that show older-overyounger as well as younger-over-older thrust relations. Two major thrust plates are present in the area. The structurally lower plate is exposed from the area of Pintlar and Warren Peaks eastward to the map boundary (fig. 2). This plate consists of tectonically juxtaposed Helena, Snowslip, and Mount Shields Formations of Proterozoic age. Isolated but important outcrops of Paleozoic carbonate rocks topographically lower than and apparently structurally below these Belt rocks are present along the southeast side of the range, suggesting that this plate is at least partly underlain by Paleozoic sedimentary rocks. Similar structural relations are interpreted for the Grasshopper plate of Ruppel and others (1981) on the south side of the Big Hole basin in the Pioneer Mountains.

Imbricate thrust faults with common youngerover-older relations deform the lower thrust plate from East Pintlar Peak northeastward to the Storm Lake area. These faults define a zone of westward younging, anastomosing thrust faults that becomes wider to the northeast. Refolding and cutting of older thrust faults is characteristic of this zone. Directly west of this zone of imbricate thrust faults is the leading edge of the structurally highest thrust plate in this area. This plate consists of stacked thrust sheets that contain an unusual carbonate-rich facies of the lower Mount Shields Formation as well as the Wallace Formation, the western facies of the middle Belt carbonate sequence.

High-angle, northeast-trending faults and shear zones cross the study area in a regular pattern. Most of these faults can be traced the entire length of the study area but do not appear to have large slip components; they are important in that they appear to have strongly influenced intrusion and orientation of some of the larger plutons exposed in the range and certainly controlled the orientation and distribution of rhyolitic to rhyodacitic dike swarms that are especially common in the western part of the study area. Several north- and northwest-trending faults are present in the map area; all appear to be minor faults and can be traced laterally only a few miles at most.

The southeastern side of the Anaconda Range is marked by a series of northeast-trending, high-angle faults along which the range was uplifted in middle Tertiary time; some of these faults may have been active during Quaternary time. 
Remote sensing

Remote sensing techniques applied to the study area included limonite mapping and the analysis of linear features. Landsat Multispectral Scanner (MSS) data were used for mapping limonite and linear features, and synthetic aperture radar (SAR) images were used in the analysis of linear features.

\section{Limonite mapping}

The distribution of limonitic exposures in the Anaconda-Pintlar Wilderness and surrounding region was recorded using digitally processed Landsat Multispectral Scanner (MSS) data. Ratios of spectral bands, which serve to emphasize small spectralreflectance contrasts while reducing the first-orderbrightness effects and variations due to topographic slope and albedo, have been used successfully to map the distribution of ferric-iron-bearing rocks in semiarid and arid regions as possible indicators of hydrothermal alteration (Rowan and others, 1974, 1977; Pohn, 1976; Podwysocki and others, 1980). However, digital-processing techniques commonly used to enhance the diagnostic spectral reflectance characteristics of iron oxide and hydrous iron oxide minerals (collectively referred to as limonite) were found to be ineffective for defining limonitic exposures in images that span the heavily vegetated parts of the Anaconda-Pintlar Wilderness and contiguous roadless area. The causes for this discrepancy are discussed by Rowan and Abrams (1978), Segal (1983), and Siegal and Goetz (1977).

The limitations in defining limonitic exposures can be overcome, in part, by consideration of the spectral characteristics of mixtures of limonitic minerals and vegetation types native to this region, in conjunction with statistical analysis of digital data derived from the Landsat MSS data for areas of known composition. It has been shown that limonitic exposures can be identified by use of a compound $(4 / 5) /(6 / 7)$ ratio (Segal, 1983). Color-ratio composite (CRC) images were produced from Landsat MSS scenes 2553-17331 and 2553-17333 by displaying the 4/5, 6/7, and $(4 / 5) /(6 / 7)$ ratios as red, blue, and green, respectively. Using this color-ratio scheme, pixels representing limonitic exposures were readily identified by their distinctive yellow and yellow-gold colors. No atmospheric corrections were made.

Several limitations of the approach used to define hyrothermally altered rocks require that reconnaissance field checking be performed. These include (1) vegetation cover greater than approximately $30-40$ percent (depending on the type, proportion, and relative concentration) tends to obscure the spectral response of limonitic areas; (2) some very bright, weakly limonitic areas display strong fron-absorption bands, and thus appear the same as strongly limonitic exposures in the CRC images; (3) limonite resulting from diagenetic processes or secondary weathering of iron-bearing minerals in unaltered rocks is not distinguishable from limonite derived from hydrothermal alteration; and (4) ironpoor altered rocks were not detected (Rowan and others, 1974).
Yellow and yellow-gold pixels representing limonitic exposures were extracted visually from the CRC images and were plotted on a 1:50,000-scale base map. Field examination of many of these areas during the summers of 1981 and 1982 by the authors and geologists conducting field studies allowed distinctions to be made between most limonitic exposures resulting from hydrothermal alteration and nonhydrothermally derived limonite. Due to time constraints, no attempts were made to characterize the dominant type of alteration on the basis of mineral assemblages or to delineate previously recognized altered rocks that did not appear distinct on the CRC images.

Through field examination of the exposures of limonitic bedrock the following subdivisions were established: (1) limonite associated with hydrothermal alteration, (2) limonite unrelated to hydrothermal alteration, and (3) limonite of undetermined origin. Limonite in the hydrothermally altered rocks is a variable mixture of ferric-oxide and hydrous ferricoxide minerals, including goethite and hematite, quartz, and, locally, jarosite. The limonite is formed through oxidation of iron sulfide minerals, mainly pyrite, and ferromagnesian and ferrous opaque minerals. In the limonitic but unaltered rocks, the source of the limonite is oxidation of ferromagnesian and ferrous opaque minerals, such as magnetite. Most of the areas where the limonite is classified as being of undetermined origin were not evaluated in the field. Approximately 58 percent of the area consisting of limonitic rock was judged to be related to hydrothermal alteration (shown on fig. 3); 21 percent was placed in each of the other two categories.

The largest area of limonitic hydrothermally altered rocks is near Mount Evans at the northeastern border of the wilderness (fig. 3 ). This area of limonitic rocks is elongate northwest to southeast and coincident with geochemical anomalies. Elsewhere, trends are not readily evident in the distribution of the altered rocks, which probably are obscured by vegetation cover and glacial deposits. Coincidence of altered areas and geochemical anomalies is variable elsewhere in the map area. Good correspondence is noted in the Beaverhead Mountain area (fig. 3). There also is a good correlation between limonite related to hydrothermal alteration and an abundance of prospects in the Warren Peak area (fig. 3); however, several areas of hydrothermal limonite southwest, southeast, and east of Beaverhead Mountain either lack geochemical anomalies or show weak anomalies in one or two elements.

\section{Analysis of linear features}

Linear features were mapped on digitally processed Landsat Multispectral Scanner (MSS) colorinfrared composite images and on band 5 and band 7 black-and-white images. In addition, linear features were mapped on synthetic aperture radar (SAR) images. Although the high topographic relief in the study area causes extensive shadows where no information is available, numerous short linear features were apparent only on the SAR images (fig. 4) because of the higher spatial resolution of SAR images ( $33 \mathrm{ft}$ versus $259 \mathrm{ft}$ for MSS images). 


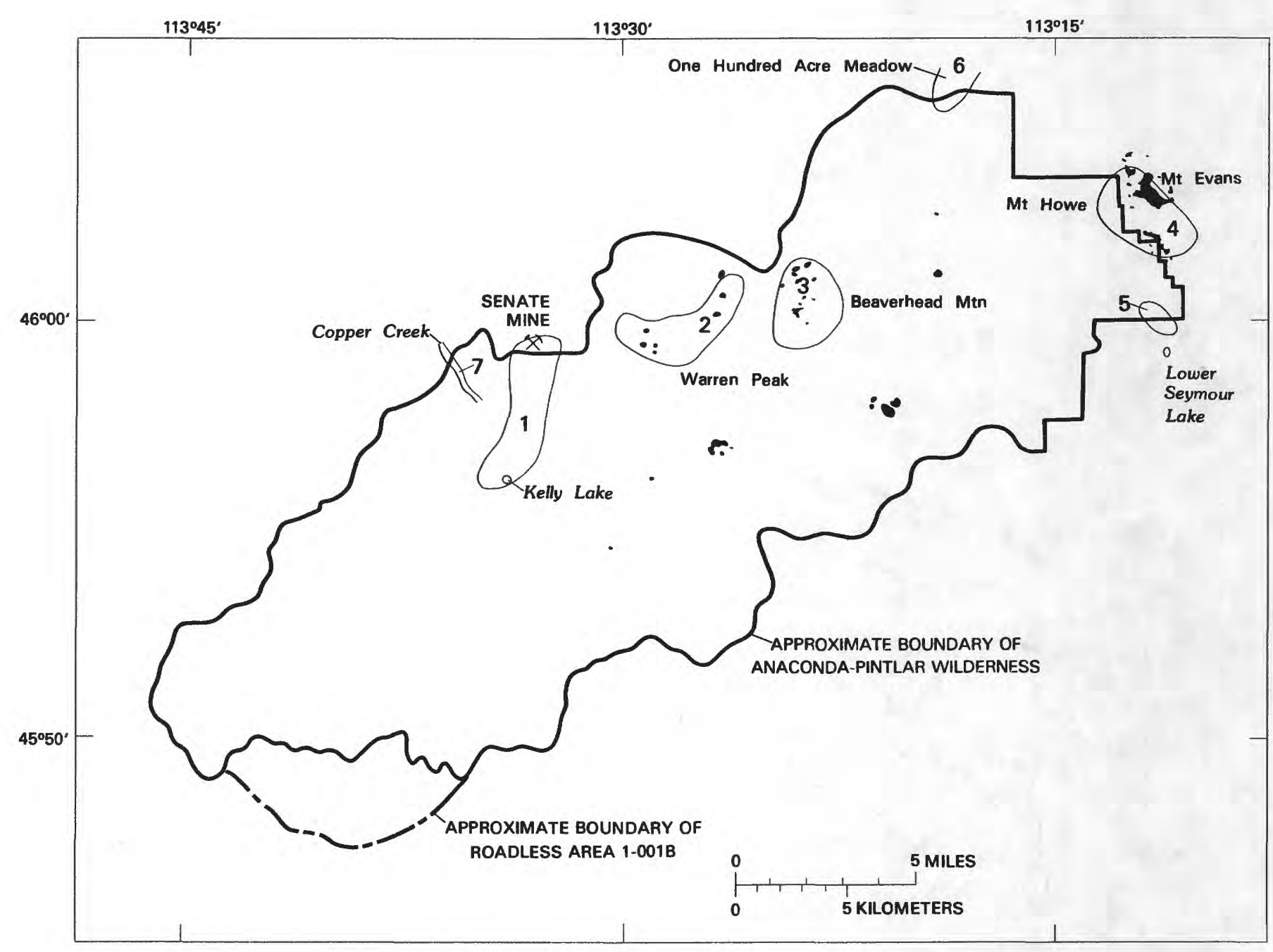

Figure 3.--Areas of limonitic rock (in black) related to hydrothermal alteration. Areas numbered 1 to 7 have moderate and moderate to high mineral resource potential 


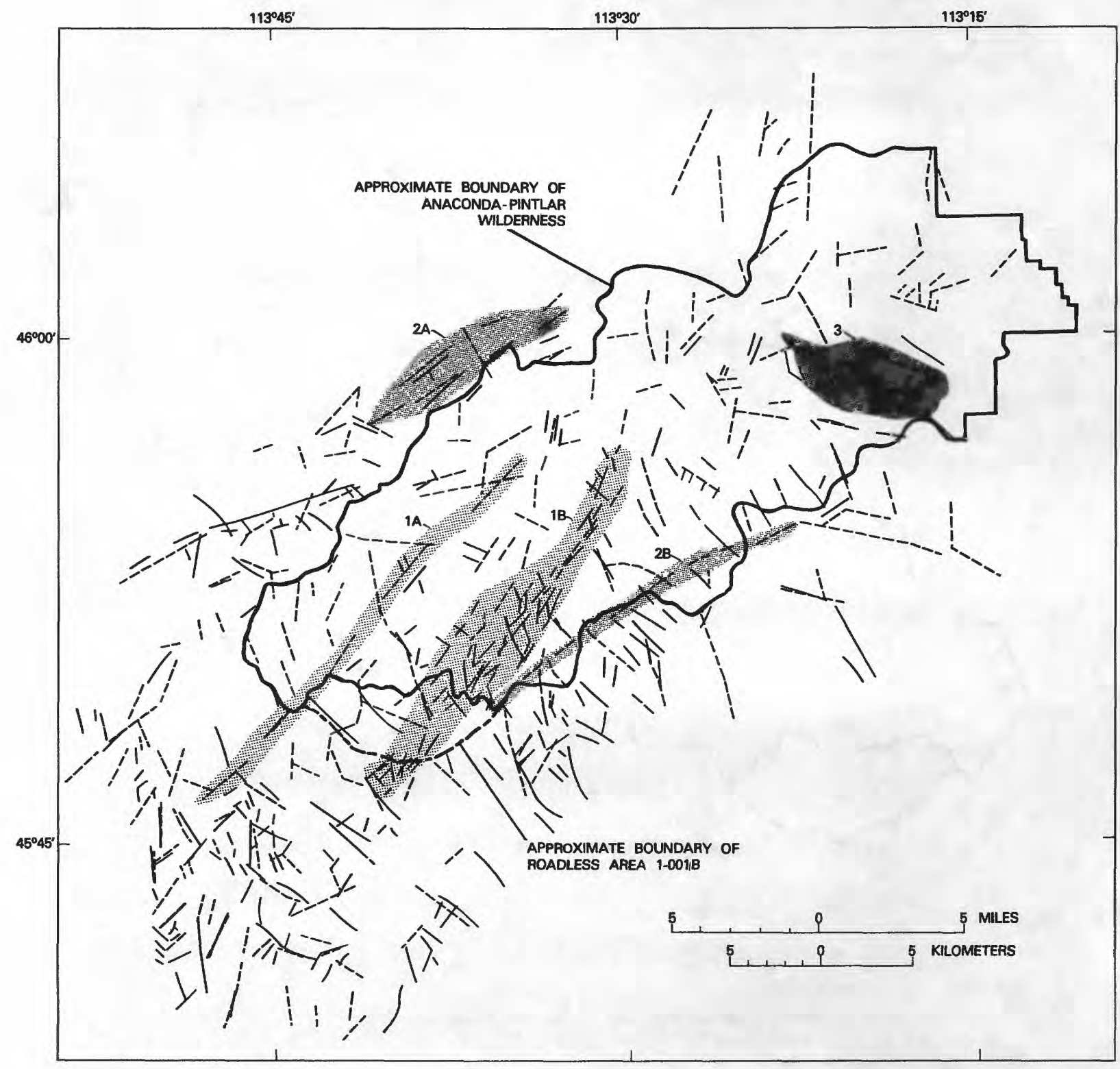

Figure 4.--Linear features of the Anaconda-Pintlar Wilderness, contiguous roadless area, and vicinity mapped on Landsat (dotted lines) and synthetic aperture radar images (solid lines) and areas of lineaments trending N. $22^{\circ}-46^{\circ} \mathrm{E} .(1 \mathrm{~A}, 1 \mathrm{~B})$ and N. $50^{\circ}-56^{\circ} \mathrm{E} .(2 \mathrm{~A}, 2 \mathrm{~B})$.

Concentrations of northwest-trending linear features also shown ( 3 ). 
The linear features were digitized and analyzed using the statistical procedure described by Sawatzky and Raines (1978). The objective of this approach is to identify maxima in the probability density function that are least likely to be random and therefore are significant. The following maxim a were determined to be statistically significant at the 90.4 percent confidence level in the length-weighted distribution: N. $1^{\circ}$ W. - N. $4^{\circ}$ E., N. $22^{\circ}-46^{\circ}$ E., N. $50^{\circ}-56^{\circ}$ E., N. $3^{\circ}-6^{\circ}$ W., N. $14^{\circ}-23^{\circ}$ W., N. $28^{\circ}-34^{\circ}$ W., N. $42^{\circ}-50^{\circ}$ W., N. $57^{\circ}-59^{\circ}$ W., N. $69^{\circ}-72^{\circ}$ W., and N. $76^{\circ}-77^{\circ}$ W. Within three of these maxima, a 1 degree interval is included, even though it lies within the nonsignificant field.

Lineaments, which are defined here as concentrations of aligned linear features, were delineated using contour maps of the areal distribution of the linear features that constitute each of the maxima. Most of the maxima consist of widely distributed linear features so that no lineaments were recognized. How ever, two lineaments were delineated in each of the maxima trending N. $22^{\circ}-46^{\circ}$ E. and N. $50^{\circ}-56^{\circ} \mathrm{E}$. The locations of these four lineaments and of one concentration of generally northwest trending linear features are shown on figure 4. Although the concentration does not have the high length-width ratio that characterizes the four northeast-oriented lineaments, it may be a local expression of an extensive fracture zone.

The two lineaments oriented N. $22^{\circ}-46^{\circ}$ E. consist of linear features that have substantially different lengths (1A and $1 \mathrm{~B}$ on fig. 4). The more easterly of these two is made up of linear features that are generally about $0.3-0.9 \mathrm{mi}$ long, whereas those that make up the lineament to the west are approximately $1.25-2.5 \mathrm{mi}$ long.

The N. $22^{\circ}-46^{\circ}$ E.-trending lineaments represent several types of geologic features. The lineament consisting of short linear features (1B) marks a zone of northeast-trending faults and granitic dikes. Zones of gouge typically less than 100 yd wide are common along these faults and result in narrow topographic lows. The dikes closely parallel the gouge zones and are low ridges. The lineament to the west (1 $\mathrm{A}$ on fig. 4) coincides with a major fault and shear zone (fig. 2).

The N. $50^{\circ}-56^{\circ}$ E.-trending lineaments (fig. 4) are also morphological expressions of faults and dikes. The lineament near the southeastern range front (2B) along the boundary of the study area is coincident, in part, with mapped high-angle rangemarginal faults. This lineament may join a northwestoriented segment to the northeast (fig. 4). The northwest-trending segment, lying outside the study area, is parallel to several faults mapped by Ruppel and others (1982) in the northern Pioneer Mountains. It is also generally coincident with the southern $\mathrm{m}$ argin of the Belt basin (Harrison and others, 1974) and appears to reflect a major northwest-trending tectonic element. The concentration of northwest-oriented linear features ( 3 on fig. 4 ) to the north also coincides with the projection of the major fault zone mapped by Ruppel and others (1982).

Linear features in the N. $50^{\circ}-56^{\circ}$ E.-trending lineament in the northwestern part of the study area (2A) are coincident with several valleys that possibly reflect unmapped faults. The cluster of northeasttrending linear features about $3 \mathrm{mi}$ southwest of this lineament is also related to topography and may indicate faults along valleys that are filled by surficial deposits.

None of the lineaments or the concentration of northwest-oriented features shows any coincidence with areas of moderate or high mineral resource potential as shown on figure 9 .

\section{Geophysical investigations}

Aeromagnetic data were acquired by contract in 1981, and gravity data were acquired during 1980-82. Regionally, gravity and magnetic contours have a generally northeastward to eastward trend, reflecting broad trends of structure, lithologic contacts, and topography. Locally, the contours show pronounced flexures and closures, reflecting surface and subsurface occurrences of plutonic and sedimentary rocks having significant contrasts of magnetizations, or densities, or both.

The principal geophysical anomalies of the study area are shown on figure 5. The study area is bordered on the west and northwest by a zoned magnetic anomaly coincident with the Sapphire batholith; a broad belt of east-southeast-trending magnetic highs, associated with intermediate plutonic rocks; a region of short-wavelength magnetic anomalies extending into the study area, typical of those associated with plutonic rocks of the Idaho batholith; and a lobed region of low-amplitude gravity lows (G1) extending into the study area, associated largely with plutonic rocks but in part covering sedimentary rocks. Near the northern margin of the study area, high-amplitude magnetic highs $\mathrm{M} 1$ and $\mathrm{M} 2$ are associated, respectively, with a buried pluton presumed to be intermediate in composition and with a partially exposed intrusive complex of intermediate composition. Low-amplitude gravity low G2, near the eastern flank of $\mathrm{Ml}$, and high-amplitude gravity high G3, overlapping $\mathrm{M} 2$ in part, are associated mostly with sedimentary rocks. Near the eastern margin of the study area, the sources of one low-amplitude magnetic high (MG1) and one high-amplitude magnetic high (M3) are unknown but are inferred to be associated with subsurface plutonic rocks. Gravity low MG1 represents the northeastern extremity of the Big Hole basin gravity low associated with low-density basin fill. Southeast of the major gravity low, a region of positive magnetic anomalies is associated with exposed plutonic rocks.

Within the study area, geophysical anomalies are subdued in amplitude relative to anomalies at the margins of the area. Low-amplitude gravity high G4 is associated largely with Precambrian sedimentary rocks, whereas low-amplitude gravity low G5 is associated largely with plutonic rocks. Magnetic highs M4 and M5, separated by magnetic low M6, are associated, respectively, with a granodiorite pluton and with the eastern margin of a monzogranite pluton. Magnetic low M6 occurs unexpectedly over the major part of the monzogranite pluton; the low may reflect subdued topography despite the draped flight profiles of the aeromagnetic survey, but more likely reflects a lower content of magnetite for the monzogranite body. Magnetic high M7 and magnetic low M8 represent another striking contrast of exposed plutonic rocks; $M 7$ is associated with part of an 


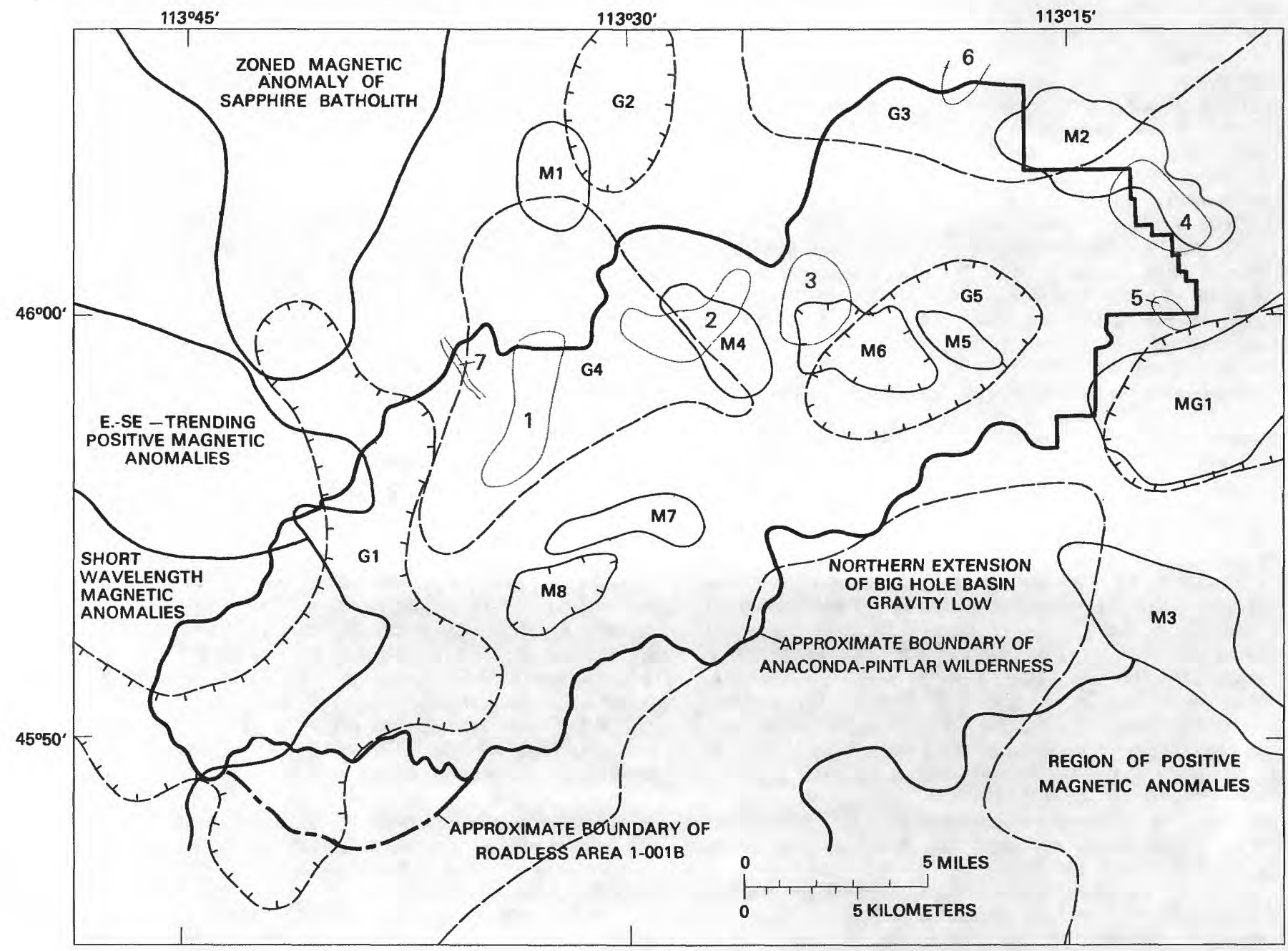

\section{EXPLANATION}

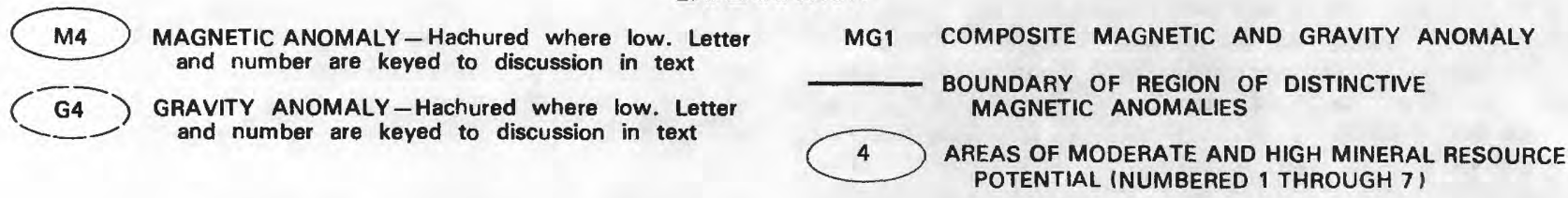

Figure 5.--Principal geophysical anomalies of the Anaconda-Pintlar Wilderness, contiguous roadless area, and vicinity. 
exposed complex of muscovite-biotite granodiorite, whereas $M 8$ is identified exclusively with a single pluton of biotite granodiorite. Magnetic low M8, like M6 to the northeast, is inferred to reflect a less magnetite-rich plutonic rock rather than reversed total magnetization; however, part of the feature may be associated with low-relief topography or a relatively thin or shallow-rooted intrusive body in the subsurface.

The geophysical data indicate that (1) lowamplitude gravity highs, such as G3 and G4, tend to delineate regions of relatively thick Paleozoic and Precambrian sedimentary rocks that have higher densities than plutonic rocks and basin fill; (2) highamplitude gravity lows, such as MGI and the northern extension of the Big Hole basin gravity low, delineate occurrences of thick accumulations of low-density basin fill; (3) high-amplitude magnetic highs, such as M2 and M4, mark occurrences of magnetite-rich intermediate-composition plutonic rocks; and (4) lowamplitude magnetic lows, such as M6 and M8, are unexpectedly associated with some plutonic rock bodies, presumably with somewhat lower contents of magnetite.

The geophysical anomalies bear general spatial relationships to areas of moderate to high mineral resource potential within the study area (fig. 5). Of greatest significance, areas $2,3,4,5$, and 6 (table 6) are associated with the flanks or central parts of magnetic highs or lows, including M2, M4, M6, and MG1.

\section{Geochemical investigations}

The geochemical survey of the Anaconda-Pintlar Wilderness and contiguous roadless area consisted of collecting and analyzing stream-sediment, pannedconcentrate, and rock samples. Of the approximately 1,050 samples collected, 272 were stream-sediment samples (sieved through a 75-micron (200-mesh) screen), 275 were panned-concentrate samples, and 506 were rock samples. The stream-sediment and panned-concentrate samples were collected from firstand second-order streams during 1980, and unweathered rock samples were collected mostly along ridgetops during 1981. All samples were analyzed for 31 elements using a six-step, semiquantitative emission-spectrographic procedure (Grimes and Marranzino, 1968) and for zinc and antimony by atomic-absorption techniques (Ward and others, 1969; Welsch and Chao, 1975). The samples were also analyzed for arsenic using a colorimetric technique (Almond, 1953). Trace-element data for the streamsediment samples can be found in Siems and others (1982). Trace-element data for rock samples can be found in Welsch and others (1983).

The results of the geochemical survey indicate anomalous concentrations of several elements in rock, stream-sediment, and panned-concentrate samples from the study area. The stream-sediment anomalies form much broader patterns than do those from rock samples. The stream-sediment anomaly patterns were used to direct the rock sampling and helped to locate the hydrothermally altered area near Beaverhead Mountain (fig. 6). However, the rock geochemical anomalies are more restricted to areas of hydrothermally altered rocks and are also more direct indicators of particular trace-element suites associated with particular rock types and of different types of mineral deposits than stream-sediment anomalies. For these reasons the geochemical discussion and interpretation of anomalies is based principally on the analytical results for rock samples.

Thresholds for geochemical anomalies for selected elements in rock samples were estimated from factors such as minimum, maximum, and mean values, frequency distributions, and standard deviations. The values considered anomalous are all greater than the 90 th percentile of the rock sample population (499 samples) and are considered to be indicative of hydrothermally mineralized rocks. Some elements, such as lead, are in anomalous concentrations in very few samples. For lead, this is generally caused by its low content in mineral deposits in the study area; if a lower threshold for lead had been selected, many samples of potassium feldsparbearing igneous rocks would have been anomalous because of relatively high background levels of lead in these rocks. This would have tended to mask those few lead values thought to be indicative of hydrothermal mineralization. Shown in table 1 are statistical analyses of geochemical data for selected elements that occur in known mineral deposits or are thought to indicate presence of hydrothermal activity in or adjacent to the study area.

\section{Commodities}

The study area has resource potential for copper, gold, lead, molybdenum, silver, tin, tungsten, and zinc. High concentrations of these elements have been detected in stream-sediment, panned-concentrate, and rock samples collected during the geochemical survey and in samples from the investigation of prospects. Other elements that occur in high concentrations in samples, but not high enough to be of interest as resource commodities, are beryllium, arsenic, antimony, and fluorine. The distribution and levels of concentration of these are important, however, because they commonly are part of suites of elements that are characteristic of certain kinds of hydrothermal deposits in the study area. In these suites they are associated with elements for which the area has resource potential such as copper, gold, lead, molybdenum, silver, tungsten, tin, and zinc.

\section{Copper}

Results of geochemical sampling indicate that anomalous concentrations of copper are found in rock samples from three areas and are closely associated with hydrothermally altered rocks. These are the Senate mine, the Beaverhead Mountain (fig. 6), and the Mount Evans-Mount Howe (fig. 7) areas. In the Senate mine area, 10 samples had anomalous values of 200 ppm to greater than $20,000 \mathrm{ppm}$ copper. Together with silver, copper is the commodity of highest resource potential in the Senate mine area and is present in higher concentrations there than elsewhere in the study area.

From the Beaverhead Mountain area, 10 samples had high copper contents in the range of 200 to 20,000 ppm (table 2). In samples from the Mount EvansMount Howe area, copper is in anomalous amounts but 
Table 1.--Statistical analys is of selected elements in rock samples

[A]l values are given in parts per million. $G$ is greater than and $L$ is less than value in parentheses. Basic statistics are calculated only on those samples with values above the detection limit for that element. Total population equals 499 samples]

\begin{tabular}{|c|c|c|c|c|c|c|c|c|c|}
\hline $\begin{array}{l}\text { Ele- } \\
\text { ment }\end{array}$ & $\begin{array}{l}\text { Detec- } \\
\text { tion } \\
\text { limit }\end{array}$ & $\begin{array}{l}\text { No. of } \\
\text { samples } \\
\text { above } \\
\text { detection } \\
\text { limit }\end{array}$ & Minimum & Maximum & $\begin{array}{c}\text { Arithmetic } \\
\text { mean }\end{array}$ & $\begin{array}{l}\text { Standard } \\
\text { deviation }\end{array}$ & Threshold & $\begin{array}{l}\text { No. of } \\
\text { samples } \\
\text { above } \\
\text { threshold }\end{array}$ & $\begin{array}{l}\text { Percent of } \\
\text { samples } \\
\text { considered } \\
\text { anomalous }\end{array}$ \\
\hline
\end{tabular}

\begin{tabular}{|c|c|c|c|c|c|c|c|c|c|}
\hline \multirow[b]{2}{*}{$\begin{array}{l}\mathrm{Ag}-\cdots- \\
\mathrm{Be}-\cdots \\
\mathrm{Cu}-\cdots \\
\mathrm{Mo}-\cdots \\
\mathrm{Pb}-\cdots \\
\mathrm{Sn}-\cdots \\
\mathrm{W}-\cdots-\end{array}$} & \multicolumn{8}{|c|}{ Analyzed by emission spectrographic methods } & \multirow[b]{2}{*}{$\begin{array}{l} \\
4.8 \\
3.4 \\
4.2 \\
5.8 \\
2.6 \\
7.4 \\
2.4\end{array}$} \\
\hline & $\begin{array}{r}0.5 \\
1.0 \\
5.0 \\
5.0 \\
10.0 \\
10.0 \\
50.0\end{array}$ & $\begin{array}{l}121 \\
471 \\
294 \\
100 \\
470 \\
39 \\
15\end{array}$ & $\begin{array}{r}0.5 \\
1.0 \\
5.0 \\
5.0 \\
10.0 \\
10.0 \\
50.0\end{array}$ & $\begin{array}{r}1,000 \\
1,000 \\
G(20,000) \\
2,000 \\
G(20,000) \\
200 \\
2,000\end{array}$ & $\begin{array}{r}29.8 \\
6.9 \\
181.4 \\
71.4 \\
103.5 \\
27.2 \\
344.8\end{array}$ & $\begin{array}{r}148.4 \\
51.4 \\
812.9 \\
235.9 \\
688.0 \\
42.7 \\
537.0\end{array}$ & $\begin{array}{c}1.5 \\
10 \\
150 \\
20 \\
100 \\
L(10) \\
L(50)\end{array}$ & $\begin{array}{l}24 \\
17 \\
21 \\
29 \\
25 \\
37 \\
12\end{array}$ & \\
\hline \multicolumn{10}{|c|}{ Analyzed by various wet-chemical methods } \\
\hline $2 n---$ & 5.0 & 444 & 5.0 & $G(2,000)$ & 50.0 & 119.1 & 140 & 11 & 2.2 \\
\hline Sb---- & 2.0 & 23 & 2.0 & $G(200)$ & 20.2 & 36.8 & $L(1)$ & 23 & 4.6 \\
\hline As- - & 10.0 & 203 & 10.0 & 2,000 & 28.0 & 144.2 & 15 & 46 & 9.2 \\
\hline
\end{tabular}


Table 2.--Analyses (in parts per million) for selected trace elements in rock samples from the

\section{Beaverhead Mountain area}

[Elements determined by semiquantitative emission spectrography include $\mathrm{Mo}, \mathrm{Sn}, \mathrm{W}, \mathrm{Cu}, \mathrm{Ag}, \mathrm{Bi}$, and $\mathrm{Be}$. Elements determined by wet-chemical techniques include $A s, S b, F, Z n$. Leaders (---) indicate low values (at or below threshold. Sample localities shown on figure 6]

\begin{tabular}{|c|c|c|c|c|c|c|c|c|c|c|c|c|}
\hline $\begin{array}{l}\text { Sample } \\
\text { No. }\end{array}$ & Mo & Sn & W & $\mathrm{Cu}$ & $\mathrm{Ag}$ & As & Sb & $\mathbf{F}$ & $B i$ & $\mathrm{Be}$ & Zn & Sample description \\
\hline 27 & 200 & $\cdots$ & 500 & $\cdots$ & 2 & 20 & 20 & $\cdots$ & $G(1,000)$ & $\cdots$ & $-\cdots$ & $\begin{array}{l}\text { Quartz vein; vuggy, } \\
\text { comb-textured. }\end{array}$ \\
\hline 39 & 30 & 10 & 50 & $-\cdots-$ & -- & 20 & 2 & 800 & - & $-\ldots$ & $-\cdots$ & Greisen. \\
\hline 40 & 100 & 20 & 50 & -.....- & -- & 20 & 2 & 1,700 & - - & 500 & $-\cdots-$ & $\begin{array}{l}\text { Quartz vein; with } \\
\text { beryl (?). }\end{array}$ \\
\hline 41 & -- & -- & 70 & 200 & -- & --- & 5 & 1,400 & - - - & 15 & $\ldots$ & $\begin{array}{l}\text { Clay-gouge; along } \\
\text { fault in } \\
\text { granodiorite. }\end{array}$ \\
\hline 42 & 50 & -- & 50 & 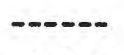 & 2 & 200 & 3 & $\cdots$ & $\ldots$ & $-\cdots$ & --- & Quartz vein. \\
\hline 43 & 50 & 150 & 2,000 & 2,000 & 50 & -- & 4 & $\ldots$ & 100 & 1,000 & 440 & Do. \\
\hline 44 & 200 & 70 & $-\cdots$ & 300 & 50 & --- & $-\ldots--$ & -...- & $\ldots \ldots$ & $\cdots$ & $\cdots$ & $\begin{array}{l}\text { Quartz vein; with } \\
\text { silver-chloride(?). }\end{array}$ \\
\hline 45 & 150 & 20 & 500 & 20,000 & 30 & 400 & $G(200)$ & 800 & -....-- & ---- & 500 & Quartz vein. \\
\hline 59 & --- & 30 & $-\cdots$ & 500 & -- & --- & ----- & 1,700 & $-\cdots-\cdots$ & 50 & $-\cdots$ & $\begin{array}{l}\text { Porphyry dike; with } \\
\text { sulfides. }\end{array}$ \\
\hline 60 & -- & 15 & $\cdots$ & $-\ldots$ & -- & $\cdots$ & ----- & $-\ldots$ & 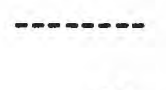 & $\cdots$ & $-\cdots-$ & $\begin{array}{l}\text { Rhyolite porphyry dike; } \\
\text { with smoky quartz eyes }\end{array}$ \\
\hline 61 & 150 & -- & $\ldots$ & $-\ldots$ & -- & -- & $\cdots-$ & $\cdots$ & 30 & $\cdots$ & $\cdots$ & Brecciated dike. \\
\hline 62 & --- & 10 & $\cdots+-$ & 200 & -- & -- & ---- & $-\ldots$ & $-\cdots-\ldots$ & $-\cdots$ & $-\cdots$ & $\begin{array}{l}\text { Chalcedony veinlet in } \\
\text { granodiorite. }\end{array}$ \\
\hline 63 & -- & 10 & $-\cdots$ & $-\ldots$ & -- & -- & ----- & $-\cdots$ & $-\cdots-$ & $\cdots$ & $-\cdots-$ & $\begin{array}{l}\text { Granodiorite; with } \\
\text { disseminated sulfides. }\end{array}$ \\
\hline 64 & -- & 15 & $-\cdots$ & $-\cdots$ & -- & --- & ----- & $-\cdots$ & - - & ---- & $\ldots$ & $\begin{array}{l}\text { Rhyolite porphyry dike; } \\
\text { smoky quartz eyes. }\end{array}$ \\
\hline 88 & -- & -- & $\cdots$ & 200 & 2 & 20 & $-\cdots$ & $-\cdots$ & $\cdots$ & $\cdots$ & $\cdots$ & Limestone; silicified. \\
\hline 89 & 50 & 30 & 200 & 200 & 20 & 30 & ----- & $-\cdots$ & 20 & $-\cdots$ & $-\cdots$ & Aplite dike. \\
\hline 92 & $-\cdots$ & 200 & $-\cdots$ & $-\cdots-$ & -- & -- & ----- & $\cdots-$ & - - & ---- & 2,200 & $\begin{array}{l}\text { Skarn; with diopside } \\
\text { and epidote. }\end{array}$ \\
\hline 93 & -- & 30 & $\cdots$ & $-\cdots$ & -- & -- & ----- & $-\cdots$ & - - & ---- & ---- & Skarn; with garnet. \\
\hline P35 & 30 & $--\cdot$ & $-\cdots$ & 700 & 5 & 30 & ----- & ---- & 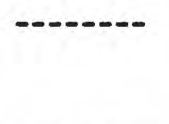 & 150 & $-\ldots$ & $\begin{array}{l}\text { Quartz vein; with } \\
\text { sulfides and } \\
\text { malachite. }\end{array}$ \\
\hline P38 & 50 & -- & $-\cdots$ & $-\cdots--$ & 3 & -- & $-\cdots-$. & $-\cdots$ & 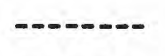 & $-\cdots$ & $\cdots$ & Quartz vein. \\
\hline P41 & -- & -- & $\cdots$ & $-\cdots-$ & -- & 140 & $\cdots-$ & $-\cdots$ & $\cdots+-\infty$ & $\cdots$ & $\ldots$ & $\begin{array}{l}\text { Porphyry dike; } \\
\text { slightly limonitic. }\end{array}$ \\
\hline P45 & 700 & -- & 50 & ----- & 2 & --- & $-\cdots--$ & $\cdots$ & 200 & $\cdots$ & $-\ldots$ & $\begin{array}{l}\text { Quartz vein; with } \\
\text { pyrite and limonite. }\end{array}$ \\
\hline P46 & 200 & 150 & 70 & 700 & 7 & 700 & $-\cdots--$ & $\cdots--$ & 20 & 10 & --- & $\begin{array}{l}\text { Quartz vein; } \\
\text { limonitic. }\end{array}$ \\
\hline P48 & 30 & 10 & $\cdots$ & 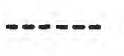 & -- & 110 & $-\cdots-$ & $-\cdots$ & 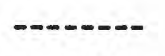 & $-\cdots$ & $-\cdots$ & Granodiorite; altered. \\
\hline P55 & -- & 10 & $\cdots$ & -..-- & 1.5 & --- & ---- & --- & 100 & 10 & $-\cdots$ & $\begin{array}{l}\text { Monzogranite; with } \\
\text { quartz veinlets. }\end{array}$ \\
\hline
\end{tabular}




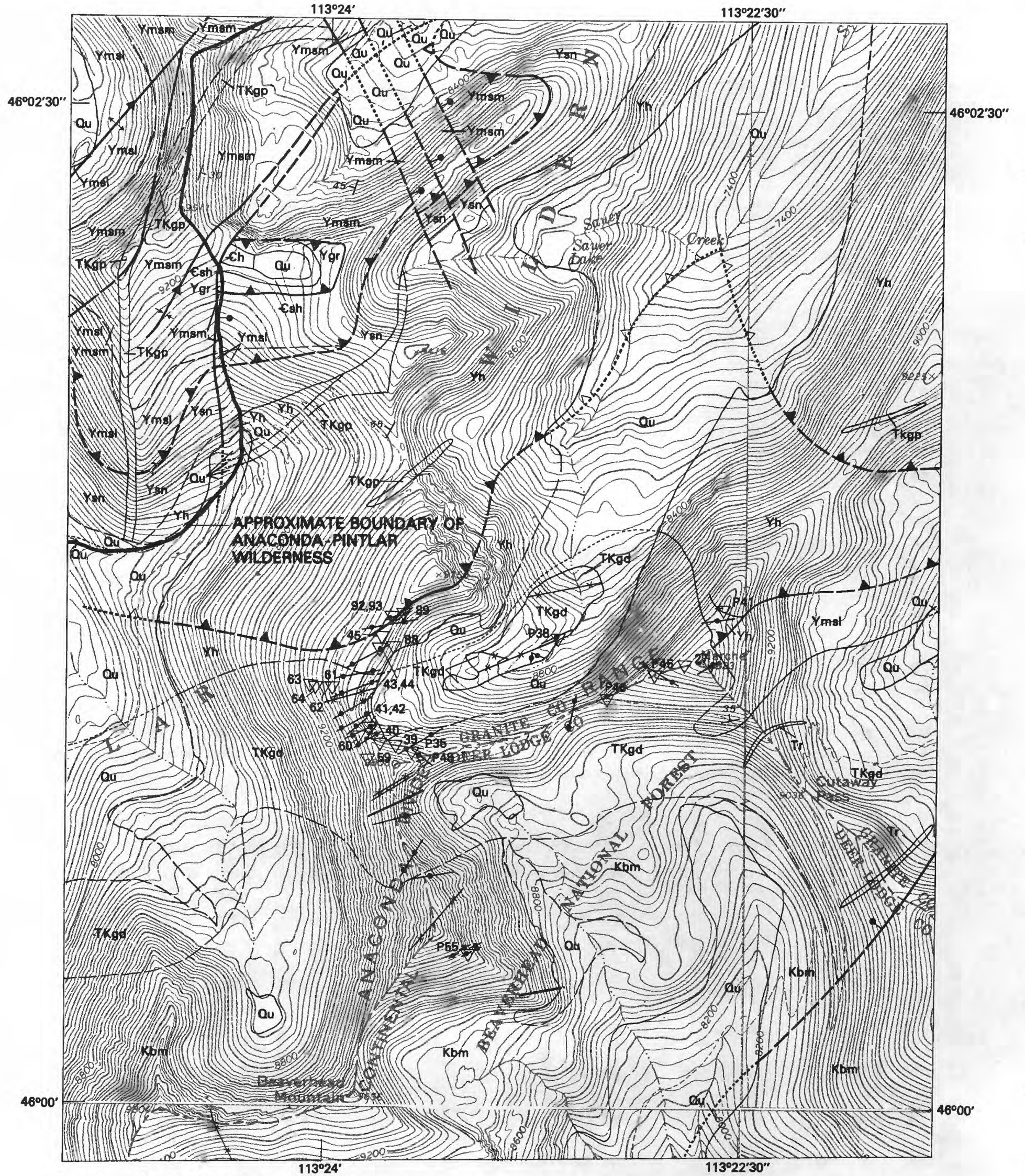

Base from U.S. Geological Survey, 1:24,000 Carpp Ridge, 1971, Warren Peak, 1962. and Storm Lake, 1971 SCALE

0

4 


\section{LIST OF MAP UNITS}

Qu Quaternary surficial deposits

Tr* $*_{*}$ Tertiary rhyolite dikes

TKg.p Tertiary to Cretaceous granodiorite porphyry and dacite porphyry dikes

TKgd Tertiary to Cretaceous hornblende-biotite granodiorite

$\mathrm{Kbm} \quad$ Cretaceous biotite monzogranite

Eh Cambrian Hasmark Dolomite

Esh Cambrian Silver Hill Formation

Ygr Proterozoic Y Garnet Range Formation

Ymsm Proterozoic $Y$ Mount Shields Formation, middle member

Yms 1 Proterozoic $Y$ Mount Shields Formation, lower member

Ysn Proterozoic $Y$ Snows lip Formation

$\mathrm{Yh} \quad$ Proterozoic $Y$ Helena Formation

\section{EXPLANATION OF MAP SYMBOLS}

Contact--Long-dashed where approximately located; short-dashed where covered by younger deposits

Fault--Long-dashed where approximately located; short-dashed where covered by younger deposits; bar and ball on downthrown side

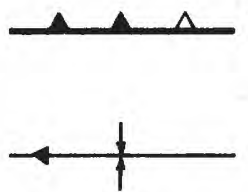

Thrust fault--Long-dashed where approximately located; short-dashed and open sawteeth where covered by younger deposits; sawteeth on upper plate

Syncline--Showing trace of axial plane and direction of plunge. Long-dashed where approximately located; short-dashed where covered by younger deposits

\footnotetext{
$\longleftarrow$ Anticline--Showing trace of axial plane and direction of plunge

$\stackrel{65}{\perp}$ Strike and dip of beds

$\because$ Quartz vein

$\nabla^{27} \quad$ Sample locality--Data in table 2
}

Figure 6.--Geology and localities of samples containing anomalous concentrations in the Beaverhead Mountain area. 


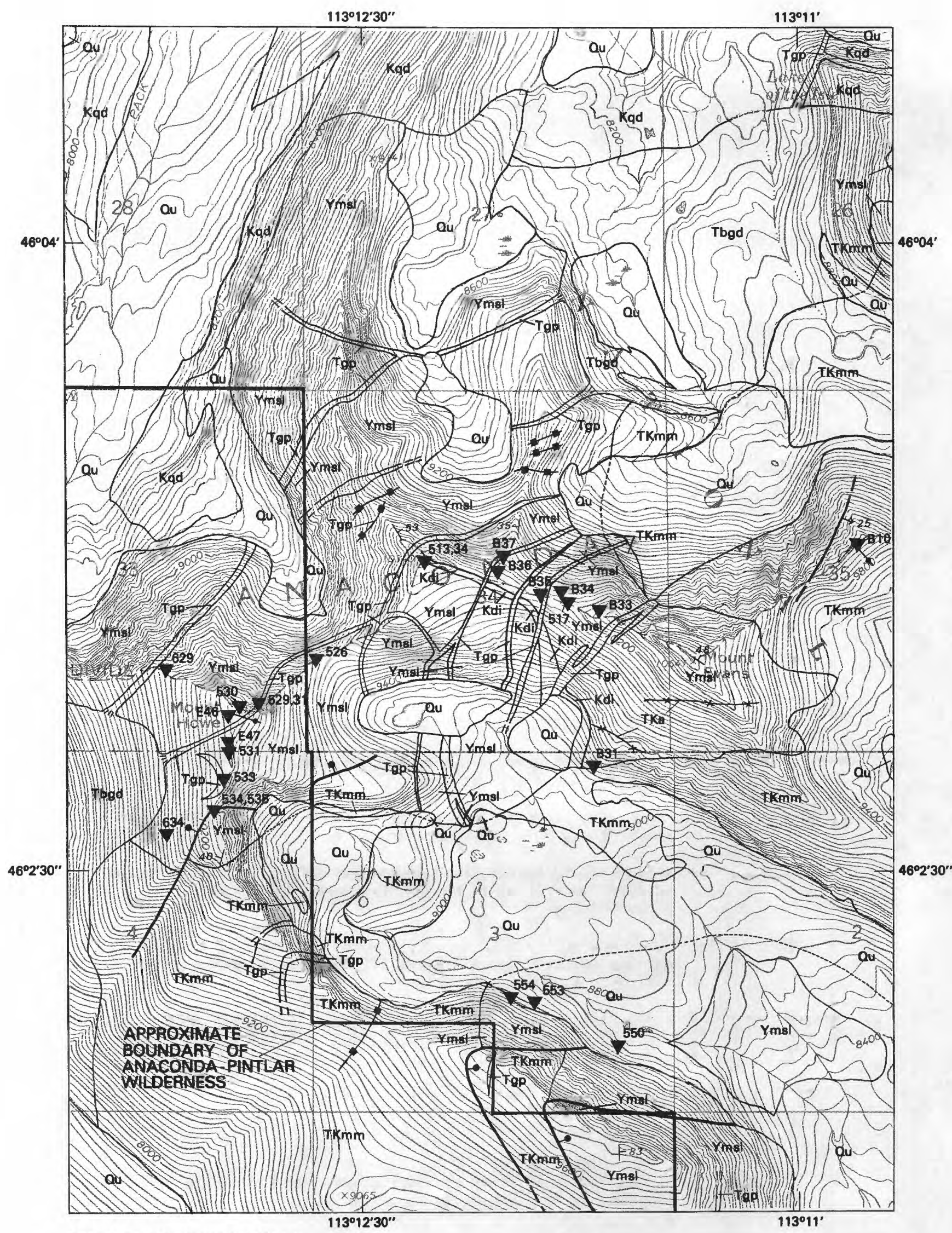

Base from U.S. Geological Survey

Mount Evans, $1: 24,000,1971$

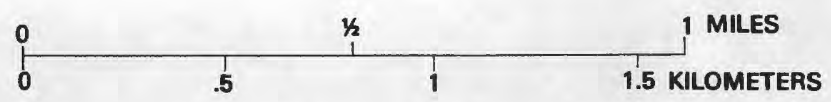




\section{LIST OF MAP UNITS}

Qu Quaternary surficial deposits

Tgp Tertiary granodiorite porphyry and dacite porphyry dikes

Tbgd Tertiary biotite granodiorite

TKa Tertiary to Cretaceous aplite dikes

TKmm Tertiary to Cretaceous biotite-muscovite leucomonzogranite

Kdi Cretaceous diorite dike

Kqd Cretaceous quartz diorite

Yms 1 Proterozoic $Y$ Mount Shields Formation, lower member

\section{EXPLANATION OF MAP SYMBOLS}

Contact--Long-dashed where approximately located; short-dashed where covered by younger deposits

\footnotetext{
$\Longrightarrow$ Gradational contact

$\stackrel{83}{\perp}$ Strike and dip of beds

$\rightarrow$ Quartz vein

$\nabla^{833}$ Sample locality--Data in table 3
}

11 Fault--Long-dashed where approximately located; bar and ball on downthrown side; arrow shows dip of fault plane

Figure 7.--Geology and localities of samples containing anomalous concentrations in the Mount Howe-Mount Evans area. 
Table 3.--Analyses (in parts per million) for selected trace elements in rock samples from the Mount Evans-Mount Howe area

[Elements determined by semiquantitative emission spectrography include Mo, $\mathrm{Sn}$, $\mathrm{Cu}, \mathrm{Ag}, \mathrm{Bi}, \mathrm{Pb}$, and $\mathrm{Be}$. Elements determined by wet chemical techniques include $\mathrm{Zn}$ and $\mathrm{F}$. Leaders (--)) indicate low values (at or below threshold). Sample localities shown on figure 7]

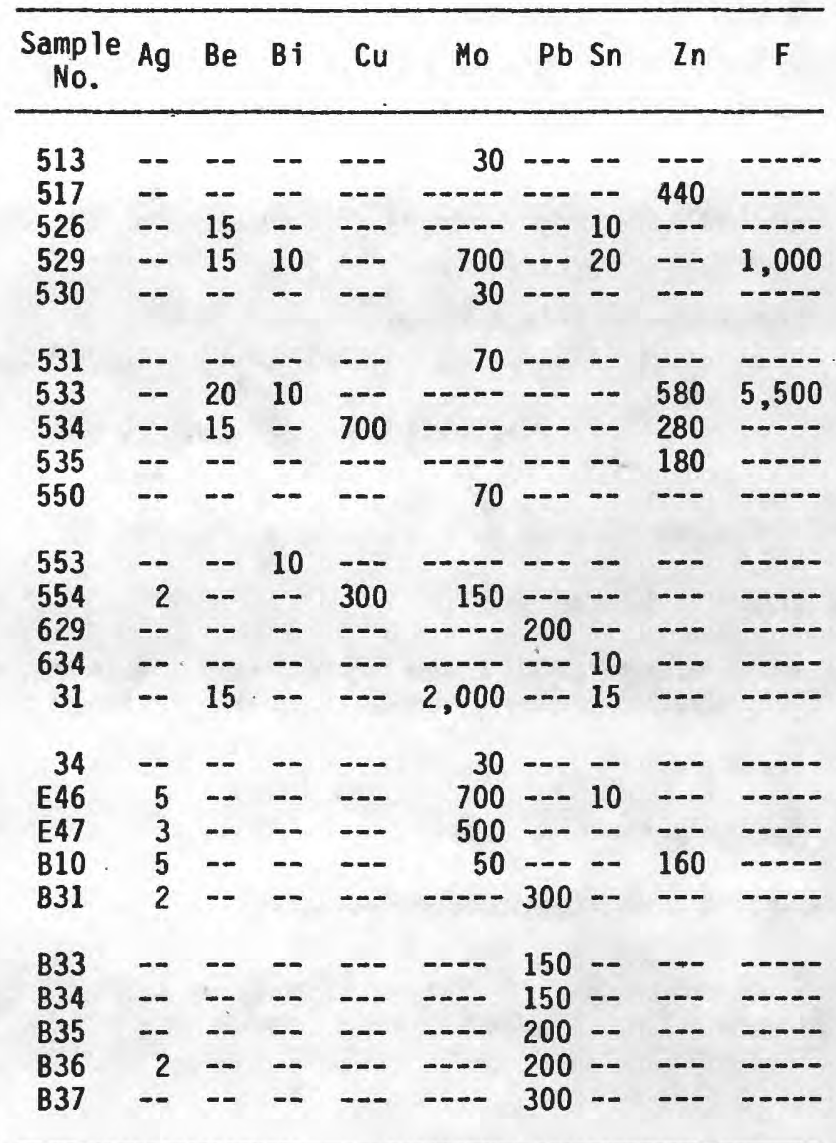


in fewer samples and at lower concentrations. The highest values detected were 300 and $700 \mathrm{ppm}$ in two samples from this area (table 3 ).

In the investigation of prospects, copper was found as a common constituent in veins of the Senate mine-Kelly Lake, the Warren Peak, and the Rainbow Mountain-Storm Lake areas (table 5). Copper-bearing minerals that have been identified at prospects include chalcopyrite, tetrahedrite, azurite, and malachite.

\section{Gold}

Gold was not determined in less than 200-mesh stream-sediment and rock samples but was analyzed for and detected in panned-concentrate samples. Gold was detected (limit of detection is $0.05 \mathrm{ppm}$ ) in concentrations ranging from 0.06 to $0.72 \mathrm{ppm}$ in six panned-concentrate samples. Only two are from within the wilderness--from Copper Creek which drains the Senate mine-Kelly Lake area and is a tributary of Middle Fork Rock Creek. Three of the anomalous samples are from streams north of the wilderness that drain the Rainbow Mountain-Storm Lake area, and one is from a small stream that drains the area of the Senate mine.

Gold was detected in many samples of veins at prospects but usually only in trace amounts. The highest gold value determined was $4 \mathrm{ppm}$; all other values were less than 1 ppm. In prospects, gold probably occurs in its native form in association with silver and other metals in quartz veins.

Lead

Lead was detected in anomalous concentrations (greater than $100 \mathrm{ppm}$ ) in about 25 rock samples collected during the geochemical survey of the study area. About two-thirds of these are associated with hydrothermal veins and altered rock, and the remainder are from samples of felsic igneous rocks from scattered localities in the wilderness. The highest concentrations of lead were in samples from the Senate mine area where five anomalous samples ranged from $150 \mathrm{ppm}$ to greater than $20,000 \mathrm{ppm}$. In samples from the Mount Evans-Mount Howe and Lower Seymour Lake areas (figs. 7,8 ) lead is also found in anomalous concentrations but at lower levels than in the Senate mine area; in the Mount Evans-Mount Howe area seven anomalous rock samples and in the Lower Seymour Lake area five anomalous rock samples had a range of 150 to 300 ppm lead (tables 3,4 ).

Lead is a common constituent of veins at many prospects, especially those in the Senate mine-Kelly Lake and Warren Peak areas where it is generally present as galena and is commonly associated with silver.

\section{Molybdenum}

Molybdenum is commonly found in anomalous concentrations in rock samples from the study area, but these anomalies are restricted to areas of hydrothermally altered rocks. The greatest number of anomalous samples (14) was collected from the Beaverhead Mountain area; their molybdenum contents ranged from 30 to $700 \mathrm{ppm}$ (table 2). Molybdenum also occurred in anomalous concentrations ranging from 30 to 2,000 ppm (table 3) in 11 samples from the Mount Evans-Mount Howe area. Other areas where molybdenum is present in anomalous amounts are the Lower Seymour Lake area (four samples ranged from 30 to $700 \mathrm{ppm}$ (table 4)) and the Senate mine area (two samples contained 70 and $500 \mathrm{ppm}$ ).

In the investigation of prospects, molybdenum was detected in vein samples from the Muloney Basin prospect (fig. 9, no. 16; table 5) and at the Logger No. 1 claim (fig. 9, no. 40; table 5). Molybdenum occurs as molybdenite and ferrimolybdite in quartz veins and altered rocks in areas of hydrothermally mineralized rock.

\section{Silver}

Anomalous concentrations of silver in rock samples are mostly restricted to areas of hydrothermal veins and altered rock; these include the Senate mine, the Beaverhead Mountain, the Mount Evans-Mount Howe, and the Lower Seymour Lake areas. The greatest number of anomalous samples (eight) and the highest values (2-50 pppm) are from the Senate mine area. In 12 samples from the Beaverhead Mountain area, silver concentrations range from 1.5 to $50 \mathrm{ppm}$ (table 2). Six anomalous samples that had silver contents ranging from 2 to $5 \mathrm{ppm}$ (table 3 ) were collected in the Mount Evans-Mount Howe area, and five rock samples that had silver contents in the range of 2 to $20 \mathrm{ppm}$ (table 4) came from the Lower Seymour Lake area. Most samples containing anomalous concentrations of silver are from quartz veins, but some samples of altered rhyolite and granodiorite dikes contained low but anomalous concentrations (2-11 ppm).

Silver is present at nearly all known prospects that we examined and is the commodity of highest economic value in the study area. Grades of as much as about 55 oz per ton have been determined in selected vein samples (table 5). Silver is probably contained mainly in the minerals tetrahedrite and galena, which have been identified in vein samples at several localities.

$\operatorname{Tin}$

Tin occurred in low but anomalous concentrations in rock samples from the Beaverhead Mountain, Mount Evans-Mount Howe, and Lower Seymour Lake areas. Anomalous tin concentrations were found in the largest number of samples and at the highest concentrations in the Beaverhead Mountain area where 16 samples had tin contents ranging from 10 to $200 \mathrm{ppm}$ (table 2). The highest value, $200 \mathrm{ppm}$, was from a sample of skarn that also contained 2,200 ppm zinc. Rhyolite porphyry dikes consistently contained slightly anomalous concentrations of tin (10-15 ppm) in the Beaverhead Mountain area and elsewhere in the wilderness. Five rock samples from the Mount Evans-Mount Howe area had tin contents in the range of 10 to $20 \mathrm{ppm}$ (table 3), and five rock samples from the Lower Seymour Lake area had tin contents that ranged from 10 to $30 \mathrm{ppm}$ (table 4). In its distribution, tin shows a close spatial affinity to molybdenum, a common relationship that has been recognized in granite-molybdenite systems (Mutschler and others, 1981). 




Base from U.S. Geological Survey, 1:24,000

Mount Evens, 1971, Lower Seymour Lake, 1962 
LIST OF MAP UNITS

Qu Quaternary surficial deposits

Tsg Tertiary sedimentary deposits and volcanic rocks

Tgp Tertiary granodiorite porphyry dike

TKmg Tertiary to Cretaceous muscovite-biotite granodiorite

TKmm Tertiary to Cretaceous biotite-muscovite leucomonzogranite

$P_{2} \quad$ Upper Paleozoic(?) dolomite

Yms 1 Proterozoic $Y$ Mount Shields Formation--Lower member

\section{EXPLANATION OF MAP SYMBOLS}

Contact

1 Fault--Long dashed where approximately located; short dashed where covered by younger deposits; bar and ball on downthrown side

Sample locality--Data in table 4

P66 Rock sample

289 Stream-sediment sample

EB6A,B Combined stream-sediment and panned-concentrate samples

Figure 8.--Geology and localities of anomalous samples in the Lower Seymour Lake area. 
Table 4.--Analyses (in parts per million) for selected trace elements in rock, streamsediment and panned-concentrate samples for the Lower Seymour Lake area

[Elements determined by semiquantitative emission spectrography include $\mathrm{Ag}, \mathrm{Bi}, \mathrm{Cu}, \mathrm{Mo}, \mathrm{Pb}$, $\mathrm{Sn}$, and $\mathrm{W}$. Elements determined by wet chemical techniques are $\mathrm{Zn}$ and $\mathrm{F}$. Leaders $(---)$ indicate low values (at or below threshold). Sample localities shown on figure 8]

\begin{tabular}{|c|c|c|c|c|c|c|c|c|c|c|}
\hline $\begin{array}{c}\text { Sample } \\
\text { No. }\end{array}$ & $\mathrm{Ag}$ & $B i$ & $\mathrm{Cu}$ & Mo & $\mathrm{Pb}$ & Sn & $W$ & $\mathrm{Zn}$ & $F$ & Type of sample \\
\hline 287 & - & --- & -- & --- & $-\cdots$ & -.. & -- & 280 & --- & Stream sediment. \\
\hline 289 & -- &.-- & $-\cdot-$ &.-- & --- & --- & -- & 110 & $\cdots-$ & Do. \\
\hline 291 & -- & $\cdots$ & $\cdots$ & -- & -- & -- & -- & 140 & $\ldots$ & Do. \\
\hline E86A & 5 & -- & -- & $\cdots$ & -- & $-\cdots$ & $\cdots$ & 300 & $\ldots$ & Do. \\
\hline E87A & 3 & $-\cdot$ & $\cdots$ & $\cdots$ & --- & $\cdots$ & -- & $\cdots$ & $-\cdots$ & Do. \\
\hline E89A & 3 & --- & -- & $\cdots$ & -- & --- & -- & -- & $\ldots$ & Do. \\
\hline E86B & -- & $\cdots$ & $\cdots$ & -- & -+ & 30 & -- & -- & $\cdots$ & Panned concentrate. \\
\hline E87B & - & $\cdots$ & --- & $\cdots$ & $\cdots$ & 100 & 300 & --- & -.... & Do. \\
\hline E89B & 7 & 150 & 150 & $-\cdot$ & 300 & 150 & 700 & -- & -...- & Do. \\
\hline 236 & - & $\cdots$ & -- & -- & $\cdots$ & $\cdots$ & -- & 650 & $\ldots$ & Rock. \\
\hline 237 & - & $\cdots$ & -- & 30 & $\cdots$ & --- & -- &.-- & $\cdots$ & Do. \\
\hline E72 & -- & 10 & --- & -- & -- & -- & 70 & -- & ---- & Do. \\
\hline E73 & -- & $\cdots$ & -- & -- & -- & -- & --- & $\cdots$ & 1,700 & Do. \\
\hline E88A & 2 & 15 & --- & --- & 200 & 15 & -- & $-\cdots$ & $\cdots$ & Do. \\
\hline E88B & -- & 10 & $\cdots$ & 30 & $\cdots$ & $\cdots$ & -- & $\cdots$ & $-\cdots$ & Do. \\
\hline E88C & 2 & 10 & -- & -- & 300 & --- & 200 & -- & --- & Do. \\
\hline E90 & -- & 10 & -- & -- & 150 & 20 & -- & -- & -..... & Do. \\
\hline E91 & 20 & 300 &.- & 700 & 200 & 20 & --- & --- & -..- & Do. \\
\hline E92 & -- & 15 & --- & 50 & -. & 30 & --- &.-- & $\ldots$ & Do. \\
\hline P65 & 5 & 30 & --- & $-\cdots$ & 300 & 10 & -- & $\cdots$ & -..... & Do. \\
\hline P66 & 5 & 150 & -- & -.. & -- & -. & -- & 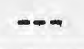 & $\ldots$ & Do. \\
\hline
\end{tabular}


Tungsten

Anomalous concentrations of tungsten occurred in only a few of the rock samples collected during the geochemical survey of the study area. Most samples that contained anomalous concentrations of tungsten, 10 that ranged from 50 to $2,000 \mathrm{ppm}$ tungsten, are from the Beaverhead Mountain area (table 2). One sample $(100 \mathrm{ppm})$ is from the Senate mine area and two (at 70 and $200 \mathrm{ppm}$ ) are from the Lower Seymour Lake area. A few other samples that contained anomalous tungsten concentrations are from scattered localities elsewhere in the wilderness.

Tungsten occurs in known deposits outside, but near, the wilderness boundary in the Rainbow Mountain-Storm Lake area in association with silver in quartz veins that cut Paleozoic carbonate rocks. In the wilderness, tungsten was detected at the Hidden Lake Prospect (fig. 9, no. 5; table 5).

Zinc

Anomalous concentrations of zinc were found only in samples of hydrothermally altered rock collected during the geochemical survey of the study area. These are from the Beaverhead Mountain area, three samples contained from 440 to 2,200 ppm (table 2); the Mount Evans-Mount Howe area, five samples in the range of 160 to $580 \mathrm{ppm}$ (table 3); and the Lower Seymour Lake area, one sample at $650 \mathrm{ppm}$ (table 4). The highest value determined, 2,200 ppm, was from a sample of a skarn zone in the Beaverhead Mountain area near the contact of granodiorite (TKgd) with Helena Formation.

The investigation of prospects shows that zinc is a common constituent of veins at many localities but does not exceed 0.5 percent (table 5). Most of the highest concentrations of zinc were in prospects from the Warren Peak area.

\section{Miscellaneous commodities}

Anomalous concentrations of beryllium, arsenic, antimony, and fluorine were detected in rock samples during the geochemical survey and investigation of prospects. These anomalies are noteworthy because one or more of these elements commonly occur in deposits with metals of resource potential, forming geochemical suites that are characteristic of certain kinds of deposits in particular geologic environments. Arsenic and antimony, for example, occur with silver, lead, and copper at the Senate mine where they form a suite characteristic of many mesothermal base- and precious-metal veins of the region. Anomalous concentrations of arsenic and antimony also occur in the Beaverhead Mountain area but in a different geochemical suite. Beryllium and fluorine are part of the geochemical suite that includes molybdenum, tin, and tungsten at the Beaverhead Mountain and Mount Evans-Mount Howe areas, similar to many granitemolybdenite systems (Mutschler and others, 1981).

The strongest arsenic anomaly is in the Senate mine area from which nine samples were collected that range from 30 to $300 \mathrm{ppm}$ arsenic. Arsenic is also contained in anomalous amounts, in the range of 20 to $400 \mathrm{ppm}$, in 11 samples from the Beaverhead Mountain area. Weak anomalies, at or slightly above $20 \mathrm{ppm}$, also occur in the Mount Evans-Mount Howe area and over a broad area southeast of the Senate mine.

Anomalies in antimony are mostly restricted to two areas; the Senate mine area, where the antimony anomaly is stronger, and the Beaverhead Mountain area. Every rock sample (14) collected in the Senate mine area contained anomalous concentrations of antimony, in the range of 2 to $160 \mathrm{ppm}$. Seven samples from the Beaverhead Mountain area contained anomalous concentrations of antimony in the range of 2 ppm to greater than 200 ppm (table 2).

Anomalous concentrations of beryllium were restricted to samples from the Beaverhead Mountain area (seven samples in the range of 10 to $1,000 \mathrm{ppm}$, table 2) and the Mount Evans-Mount Howe area (five in the range of 15 to $20 \mathrm{ppm}$, table 3). Beryl has been identified from a vein in the Beaverhead Mountain area and has also been reported from the Logger No. 1 claim (fig. 9, no. 40; table 5).

A few high concentrations of fluorine, in the range of 800 to $5,500 \mathrm{ppm}$, occurred in association with molybdenum, beryllium, and other elements in samples from the Beaverhead Mountain, Mount EvansMount Howe, and Lower Seymour Lake areas. Fluorite was identified in quartz stringers in altered, sheared granodiorite in the Lower Seymour Lake area.

\section{MINING DISTRICTS AND MINERALTATION}

\section{History and geologic setting of deposits}

Many claims have been located in the AnacondaPintlar Wilderness, but production from the area has been meager. Several deposits that have produced minor amounts of ore are located in districts within $5 \mathrm{mi}$ of the north and northwest boundaries of the wilderness. These include the Frogpond Basin, Moose Lake (fig. 9), and Silver Lake (about $4 \mathrm{mi}$ north of Storm Lake) mining districts. About 1,400 tons of ore was produced from three mines in the Frogpond Basin district during 1910-1968. Production records show that $1,103 \mathrm{oz}$ of gold, $4,352 \mathrm{oz}$ of silver, 2,409 $\mathrm{lb}$ of copper, $83,715 \mathrm{lb}$ of lead, and $22,397 \mathrm{lb}$ of zinc were recovered from the ore (Wallace and others, 1984). The productive deposits are in mesothermal quartz fissure veins in Cretaceous granodiorite and Proterozoic Belt quartzite. The Banner mine in the Moose Lake district has produced 1,979 oz of gold, $5,896 \mathrm{oz}$ of silver, and $20,935 \mathrm{lb}$ of copper from ore mined prior to 1937 and from the reworking of mine dumps during the 1970's (Wallace and others, 1984). Mesothermal quart $z$ fissure veins in Belt quartzite are the principal deposit type. In the Silver Lake district, mesothermal fissure and replacement veins and tabular replacement bodies in Paleozoic carbonate rocks have produced ore during 1884 to 1978 that contained 175 oz of gold, $76,881 \mathrm{oz}$ of silver, $25,000 \mathrm{lb}$ of copper, $95,000 \mathrm{lb}$ of lead, $55,000 \mathrm{lb}$ of zinc, and $91,670 \mathrm{lb}$ of tungsten (compiled from USGS Mineral Resource Data System records). The only production from within the wilderness is from the Barbara Ann claim near Warren Peak (no. 14, fig. 5; table 5). In 1942, 3 tons of ore was produced from this claim that yielded $124 \mathrm{oz}$ silver, $41 \mathrm{lb}$ copper, and $391 \mathrm{lb}$ lead that had a gross value of about $\$ 150$ (U.S. Bureau of Mines production records). 
Table 5.--Summary descriptions of mines, prospects, and occurrences within and contiguous to the Anaconda Pintlar Wilderness

[Wilderness prospects underlined have identified resources or potential for undiscovered resources: samples analyzed by U.S.Bureau of Mines laboratories at Reno, Nev.; gold and silver determined hy fire assay; copper, lead, zinc, molybdenum, tungsten, beryllium, and antimony determined by
atomic absorption]

\begin{tabular}{|c|c|c|}
\hline $\begin{array}{l}\text { Map } \\
\text { No. }\end{array}$ & Name & Workings \\
\hline 1 & $\begin{array}{l}\text { Copper Creek } \\
\text { prospect. }\end{array}$ & One pit-ne \\
\hline 2 & $\frac{\text { South clipper }}{\text { prospect. }}$ & One adit and one pit-_..... \\
\hline 3 & CIipper lode--.- & $\begin{array}{l}\text { One caved adit with a stope } \\
\text { to the surface, one caved } \\
\text { shaft, two trenches, and } \\
\text { one pit. }\end{array}$ \\
\hline 4 & $\begin{array}{c}\text { Ripple Lake } \\
\text { prospect. }\end{array}$ & $\begin{array}{l}\text { One caved adit and six } \\
\text { pits. }\end{array}$ \\
\hline 5 & $\begin{array}{l}\text { Hidden Lake } \\
\text { prospect. }\end{array}$ & None--_- \\
\hline 6 & Johnson claim--- & $\begin{array}{l}\text { One caved inclined shaft and } \\
\text { three pits. }\end{array}$ \\
\hline 7 & $\begin{array}{l}\text { West Little Lake } \\
\text { prospect. }\end{array}$ & One pit--..... \\
\hline B & $\begin{array}{l}\text { Pine Squirrel } \\
\text { claim. }\end{array}$ & $\begin{array}{l}\text { Five shafts and two } \\
\text { trenches. }\end{array}$ \\
\hline 9 & $\frac{\text { Ivanhoe Lake }}{\text { prospects. }}$ & $\begin{array}{l}\text { Twenty-six adits and shafts } \\
\text { and twenty pits and } \\
\text { trenches. }\end{array}$ \\
\hline
\end{tabular}

10 Copper Mountain Three caved adits and six lode. pits.

11 Senate mine----- One shaft, four adits, and ten pits and trenches.

12 Mayflower lode-- One adit and a drift with a winze.

13 Falls Fork prospect.

Two adits and one caved shaft.

14 Barbara Ann claim.

15

Muloney mine---- One adit, two caved adits, one caved shaft, one backhoe pit, and one prospect pit.

16 Muloney Basin prospect.

17 Divide prospect.

18 Silver Queen claim.

19 East Carpp Lake prospect.
Deposit type and analytical data

Ouartz vein in quartzite. One sample taken: no metals detected.

vein zone in quartzite. One of three samples across the zone had trace gold, 2.8 oz of silver/t on and 0.059 percent copper.

Ouartz vein in quartzite. Eight samples were taken. The zone contains 87,000 tons that averages 1.2 oz of silver/ton and 0.48 percent copper.

Duartz vein zone in quartzite. The best of nine samples contained trace gold, 0.2 oz of silver/ton, and 0.047 percent copper. Replacement zones along calcareous argillite interbeds in quartzite. The hest of six samples had 0.01 oz of gold/ton, 0.003 percent copper, and 0.08 percent $\mathrm{NO}_{3}$. Veins in limestane, siltite, and quartzite. Six samples taken; the best had trace gold, 0.1 oz of silver/ton, 0.053 percent copper. and 0.2 percent lead.

Silicified zone in quartzite, the hest of three samples contained trace gold and 0.1 oz of silver/ton.

Quartz veins in quartzite. Elght samples taken; the highest had trace gold and 0.2 oz of silver/ton.

Quartz vein zone along quartzite, argillite, and calcareous bers. Eighty samples taken: resources total 4,000 tons averaging $0.5 \mathrm{oz}$ of silver/ton and $1 . n$ percent lead.

Quartz vein zone in quartzite. The best of 13 samples had trace gold, 3 oz of silver/ton, 4.3 percent copper, 0.004 percent lear, and 0.014 percent zinc.

Duartz vein zone in quartzite. Seventy samples taken; the zone averaged 1 oz of silver/ton and 0.69 percent copper.

Quartz vein zone in quartzite. Ten samples taken: the zone averaged $0.45 \mathrm{oz}$ of silver/ton, 3.4 percent copper, 0.13 percent lead, and 0.08 percent zinc.

Duartz veins in shale. The hest of eight samples contained trace gold and 0.2 oz of silver/ton.

Ouartz vefins in dolomite. Twenty-six samples taken: the vein averages $0.02 \mathrm{oz}$ of gold /ton, 4.1 oz of silver/ton, 0.03 percent copper, 0.33 percent lead, and 0.12 percent zinc. Resources total 71,000 tons.

Quartz vein in dolomite. Sixteen samples taken; the best assayed 0.01 oz of gold/ton, $55.4 \mathrm{oz}$ : of silver/ton, 0.51 percent copper, 0.4 percent lead, and 0.4 percent $z$ inc.

Ouartz vein in granodiorite. One chip sample assayed 0.3 oz of silver/ton, 0.72 percent copper, 0.61 percent molybdenum.

Ouartz vein along contact between granodiorite and aplite. One chip sample across the vein had 0.021 percent copper and 0.02 percent lead.

Ouartz vein in diorite. Four samples har insignificant metal values.

Iron-stained fracture.in granodiorite. One sample had trace gold. 
Table 5.--Sumary descriptions of prospects and minerallzed areas within and contiguous to the Anaconda Pintlar Wilderness--Continued

\begin{tabular}{|c|c|c|c|}
\hline $\begin{array}{l}\text { Map } \\
\text { Mo. }\end{array}$ & Name & Workings & Deposit type and analytical data \\
\hline 20 & $\frac{\text { Rock Rabbit and }}{\text { Sunbeam }}$ & Two adits and two pits-........ & $\begin{array}{l}\text { Veins in quartzite. Twelve samples taken: } \\
\text { the best had } 0.02 \text { oz of gold/ton, } 2.5 \mathrm{oz} \text { of } \\
\text { s1lver/ton, } 0.015 \text { percent copper, and } 0.19 \\
\text { percent lead. }\end{array}$ \\
\hline 21 & $\frac{\text { North Warren }}{\frac{\text { Peak }}{\text { occurrence. }}}$ & None-- & $\begin{array}{l}\text { Vein in quartzite. One sample assayed } 0.6 \mathrm{oz} \\
\text { of silver/ton, } 0.011 \text { percent copper, } 0.51 \\
\text { percent lead, and } 0.095 \text { percent zinc. }\end{array}$ \\
\hline 22 & $\frac{\text { Narren Peak }}{\text { prospect. }}$ & Two pits-...- & $\begin{array}{l}\text { Quartz veins in quartzite. Elght samples } \\
\text { taken; the veins contain a resource of } 1,300 \\
\text { tons that averages } 1.8 \text { oz of silver/ton and } \\
1.5 \text { percent lead. }\end{array}$ \\
\hline 23 & Lookout claim--- & One pit-....................... & $\begin{array}{l}\text { Cuartz veins in quartzite. The best of six } \\
\text { samples had } 0.01 \text { oz of gold/ton, } 3.3 \text { oz of } \\
\text { silver } / \text { ton, } 0.12 \text { percent copper, } 0.75 \text { percent } \\
\text { lead, and } 0.17 \text { percent zinc. }\end{array}$ \\
\hline 24 & $\frac{\text { Lucky Seven }}{\text { claims. }}$ & One adit and two cuts--..- & $\begin{array}{l}\text { Vein in granodiorite. Four samples taken; the } \\
\text { best contained } 2.6 \text { oz of silver/ton. }\end{array}$ \\
\hline 25 & Luke clains--... & One adit and two pits........ & $\begin{array}{l}\text { Ouartz veins in quartzite. Twenty-one samples } \\
\text { taken. The veins represent a resource of } \\
17,000 \text { tons that averages } 1.4 \text { oz of } \\
\text { silver/ton and } 0.54 \text { percent lead. }\end{array}$ \\
\hline 26 & $\begin{array}{l}\text { Porter Ridge } \\
\text { prospect. }\end{array}$ & One pit-n....... & $\begin{array}{l}\text { Iron-stained pyritic quartzite. One sample } \\
\text { taken; no metals detected. }\end{array}$ \\
\hline 27 & $\begin{array}{l}\text { West Warren } \\
\text { prospect. }\end{array}$ & One pit-n & $\begin{array}{l}\text { Silicified zone in quartzite. Two samples } \\
\text { taken; no metals detected. }\end{array}$ \\
\hline 28 & $\begin{array}{c}\text { East Warren } \\
\text { prospect. }\end{array}$ & One pit-n. & $\begin{array}{l}\text { Pyritic fault zone in quartzite. Two samples } \\
\text { taken; no metals detected. }\end{array}$ \\
\hline 29 & Edith Lake------- & One pit--.....- & $\begin{array}{l}\text { Pyritic zone in diorite. One sample taken had } \\
\text { trace gold. }\end{array}$ \\
\hline 30 & $\begin{array}{l}\text { Johnson Lake } \\
\text { prospect. }\end{array}$ & Two pits_-_._. & $\begin{array}{l}\text { Quartz vefn in quartzite. Five samples taken; } \\
\text { the hest had a trace gold and } 0.2 \text { oz of } \\
\text { silver/ton. }\end{array}$ \\
\hline 31 & $\frac{\text { Rainbow pass }}{\text { occurrence. }}$ & 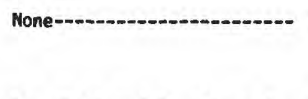 & $\begin{array}{l}\text { Vein in limestone. Two samples taken; the } \\
\text { best contained } 0.01 \text { oz of gold/ton, } 0.1 \text { oz } \\
\text { of silver/ton, and } 0.73 \text { percent copper. }\end{array}$ \\
\hline 32 & $\frac{\text { One-Hundred Acre }}{\frac{\text { Meadow }}{\text { prospect. }}}$ & $\begin{array}{l}\text { One shaft and } 15 \text { pits and } \\
\text { trenches. }\end{array}$ & $\begin{array}{l}\text { Veir in limestone. The best of six samples } \\
\text { had trace gold, zinc, and ant imony as well } \\
\text { as } 9 \text { oz of silver/ton, and } 1.3 \text { percent } \\
\text { copper. }\end{array}$ \\
\hline 33 & Monk claim--...- & $\begin{array}{l}\text { One caved adit with stopes } \\
\text { and seven pits and } \\
\text { trenches. }\end{array}$ & $\begin{array}{l}\text { Ouartz vein in dolomite. Mine samples taken; } \\
\text { the vein averages } 1.9 \text { oz of silver/ton, } 0.12 \\
\text { percent copper, } 0.03 \text { percent lead, and } 0.02 \\
\text { percent zinc. }\end{array}$ \\
\hline 34 & $\begin{array}{l}\text { Lakeview } \\
\text { placer. }\end{array}$ & $\begin{array}{l}\text { Three caved adits and three } \\
\text { pits. }\end{array}$ & $\begin{array}{l}\text { Contact zone between sedimentary and intrusive } \\
\text { rocks. Eight samples taken; the best had } \\
0.01 \text { oz of gold/ton, } 0.1 \text { oz of silver } / \text { ton. } \\
0.011 \text { percent copper, } 0.016 \text { percent lead, } \\
\text { and } 0.006 \text { percent zinc. }\end{array}$ \\
\hline 35 & $\begin{array}{l}\text { Storm Lake Pass } \\
\text { occurrence. }\end{array}$ & 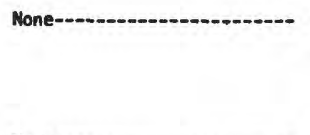 & $\begin{array}{l}\text { Vein in } 1 \text { mestone. Three samples taken; the } \\
\text { best contained } 0.01 \text { oz of gold/ton, } 0.1 \text { oz } \\
\text { of sflver/ton, } 0.002 \text { percent copper. } \\
\text { and } 0.008 \text { percent zinc. }\end{array}$ \\
\hline 36 & $\frac{\text { Kurt Peak }}{\text { occurrence. }}$ & 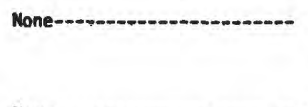 & $\begin{array}{l}\text { Vein in limestone. Three samples taken; the } \\
\text { best contained trace gold, } 0.4 \text { oz of } \\
\text { silver/ton, and } 0.065 \text { percent copper. }\end{array}$ \\
\hline 37 & Sund claims-...-- & 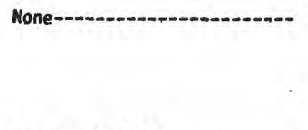 & $\begin{array}{l}\text { Contact zone between sedimentary and intrusive } \\
\text { rocks. Nine samples taken, the best had } \\
\text { trace gold, } 0.1 \text { oz of silver/ton, and } 0.007 \\
\text { percent copper. }\end{array}$ \\
\hline 38 & $\begin{array}{l}\text { East Fork } \\
\text { prospect. }\end{array}$ & Two caved adits--..-- & $\begin{array}{l}\text { Ouartz vein in granodiorite. Three samples } \\
\text { taken, the best had trace gold. }\end{array}$ \\
\hline 39 & Hauseman mine--- & $\begin{array}{l}\text { Two caved adits and two } \\
\text { pits. }\end{array}$ & $\begin{array}{l}\text { Silfcified shear zone in monzogranite. Five } \\
\text { samples taken had insignifficant metal } \\
\text { values. }\end{array}$ \\
\hline 40 & $\begin{array}{l}\text { Logger No. } 1 \\
\text { claim. }\end{array}$ & One pitw............... & $\begin{array}{l}\text { Quartz vein in granodiorite. The hest of the } \\
\text { five samples contained } 0.12 \text { oz of gold/ton, } \\
32.6 \text { oz of silver/ton, } 0.012 \text { percent copper, } \\
0.15 \text { percent lead, } 0.23 \text { percent molybdenum, } \\
\text { and } 0.69 \text { percent beryll fum. }\end{array}$ \\
\hline
\end{tabular}




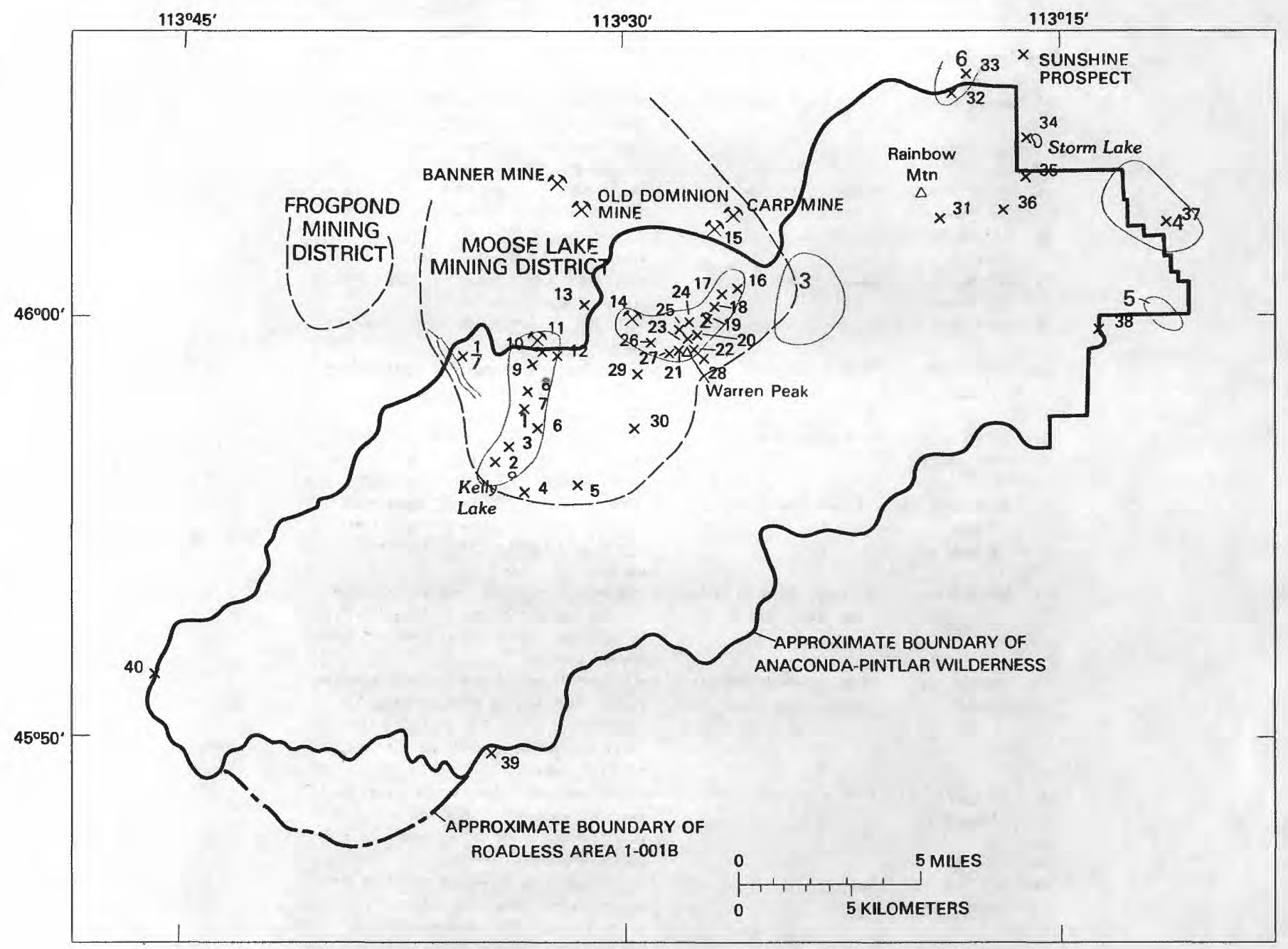

Figure 9.--Mines, prospects, occurrences, and mining districts in and adjacent to the Anaconda-Pintlar Wilderness. Areas of moderate and high mineral resource potential (numbered 1 through 7 ) also shown. 
Several mines and prospects occur outside but near the wilderness in the Moose Lake district and south of the Silver Lake district. These include the Senate mine (no. 11, fig. 9), the Carp mine on Carpp Ridge (fig. 9), and several prospects and small mines north and northwest of Storm Lake (fig. 9). Minor production has been reported for the Senate mine, the Carp mine (Emmons and Calkins, 1913), and the Sunshine prospect (Walker, 1960), north of Storm Lake (fig. 9).

Mining claim records for Beaverhead, Deer Lodge, Granite, and Ravalli Counties show that at least 90 lode claims have been located in the wilderness. Many more were probably staked but were too poorly described to find during this study. No placer claims are recorded. Records of the U.S. Bureau of Land Management list one patented claim within the wilderness boundary--the Clipper lode (no. 3, fig. 9) at the head of Copper Creek. The majority of the mining claims are in the Moose Lake mining district in the area drained by the Middle Fork Rock Creek and its tributaries. This area is bordered on the east by upper Carpp Creek, on the south by the Continental Divide, and on the west by upper parts of Copper Creek. Within this area there is a distinct clustering of prospects in the vicinity of Warren Peak and a north-northeast-trending group of prospects from the vicinity of Kelly Lake to the Senate mine (no. 11). Another group of prospects is located in the Rainbow Mountain-Storm Lake area (fig. 9) in the northeastern part of the study area; these prospects are similar in geologic settings to deposits north of the study area in the Silver Lake district.

\section{Warren Peak area}

Known deposits and occurrences in the vicinity of Warren Peak are in mesothermal fissure or replacement quartz veins. All are narrow and low in grade of contained metals. The two most important deposits in this area are the Barbara Ann and Luke claims (nos. 14 and 25, fig. 9). At the Barbara Ann claim, stringers and veins of quartz fill northeasttrending fractures in Hasmark Dolomite. The vein quartz has comb structure and many open spaces. The veins contain sparse amounts of tetrahedrite, galena, and azurite. Quartz veins at the Luke claim occur along northwest-trending fractures that dip southwest and are essentially parallel to bedding in quartzite of the Mount Shields Formation and are near a quartzitegranodiorite contact. The main vein is coarse grained, has vuggy zones, contains abundant galena and pyrite, and ranges in thickness from about 0.5 to $2.0 \mathrm{ft}$.

\section{Senate mine area}

The Senate mine (no. 11, fig. 9) is about $0.25 \mathrm{mi}$ north of the wilderness boundary and just west of Middle Fork Rock Creek. Although the mine workings are outside the wilderness, the mineralized zone explored at the mine continues south through the patented Senate and Copper Mountain lode claims (no. 10, fig. 9) and into the wilderness for more than $0.5 \mathrm{mi}$. This mineralized zone is one of several similar zones in a mineralized area about a mile wide that extends about $5 \mathrm{mi}$ south from the Senate mine to the vicinity of Kelly Lake and includes the Mayflower lode (no. 12, fig. 9) patented claim, which, like the Copper Mountain lode, forms jogs or reentrants into the wilderness. Though no records substantiate it, the Senate mine reportedly produced a small amount of copper and silver ore.

The Senate mine area was explored from 19581962 by Bear Creek Mining Company (Stentz, 1975). That work included about 20 line miles of geophysical (IP) surveys and 3,518 ft of drilling, as well as sampling and geologic studies. The richest drill intercepts contained 0.44 percent copper. The company considered the deposit too small for them to mine and did no further work.

The rock exposed at the Senate mine is thickbedded quartzite, probably of the Mount Shields Formation (Proterozoic Y), that strikes northnortheast and dips west at $30^{\circ}-50^{\circ}$.

The mineralized zone is at least $280 \mathrm{ft}$ wide at the mine, for the N. 70 W. adit of that length crosscuts the zone at approximately right angles and is mineralized throughout. The quartzite exposed in the adit and near the portal has been replaced in varying degrees by ankerite, barite, and sulfide minerals, mainly pyrite. Both the replaced and unreplaced rock are cut by shear zones and quartz veins that trend dominantly N. to N. $20^{\circ}$ E., and dip moderately to steeply both east and west. Upon weathering, the replaced rock is chocolate brown to yellowish brown, slightly friable, and commonly coated with manganese oxide. Replacement of the quartzite was not uniform. In some places, ankerite and barite in irregular blotches about 0.1 in. across are scat tered in a matrix of unaltered orthoquartzite. Where replacement progressed further, the entire rock has a matrix of carbonate and locally barite, and sand grains remain only as unreplaced cores of widely varying size and are locally absent.

The distribution of the carbonate is best seen and its replacement origin most convincingly demonstrated in outcrops near the mine, where the unreplaced quartzite stands out in relief against the more easily weathered brown carbonate-bearing rock. Bedding structures, particularly laminae, in the quartzite are irregularly and discordantly cut by the carbonatebearing rock. Certain laminae in the quartzite persist into and through the carbonate-bearing rock. In addition, unreplaced masses of quartzite commonly a few inches to a few feet across "float" in carbonatecemented rock. These masses have not been rotated, but retain the same bedding attitude as is general nearby. Evidence of replacement is also apparent microscopically; euhedral terminations of ankerite crystals penetrate the edges of the quartz grains producing a serrated grain margin.

The mineralization was probably localized by the numerous fracture zones evident in the mine workings and in surface exposures above the portal of the main adit. Chalcopyrite and pyrite are sparsely and sporadically disseminated through the carbonatealtered and unaltered quartzite throughout the workings. These minerals also occur in quartz veins that range from less than 1 in. to more than $2 \mathrm{ft}$ thick. The veins are both concordant and discordant to the bedding. Galena has also been reported.

South of the Senate mine, the mineralized zone is covered by soil and till for a distance of about 800 ft. South of the covered interval, a line of prospect 
diggings angles up the steep slope toward the southeast. These workings are probably on the same zone, as it is similar mineralogically, but here the zone is generally less than $10 \mathrm{ft}$ thick.

The sparseness of ore minerals in the Senate mine mineralized zone and the low concentrations of copper, silver, lead, and zinc in rock samples from the zone indicate that the deposits are low grade.

\section{Rainbow Mountain-Storm Lake area}

Prospects in this area include the One Hundred Acre Meadow prospect (no. 32, fig. 9), the Monk claim (no. 33), prospects near the study area to the north and the northeast of the Monk claim (including the Sunshine claim), and four prospects occurring in an arc between Storm Lake and Rainbow Mountain (fig. 9). This area has the southernmost occurrences of deposits similar to those in the Silver Lake mining district. Most of the mineral deposits in this area consist of metal-bearing quartz veins that have been emplaced along fractures, with local brecciation, in Hasmark Dolomite. Replacement of the dolomite fragments and of rock along vein walls is a minor feature. The veins are generally less than $1 \mathrm{ft}$ wide but may be as wide as $6 \mathrm{ft}$.

The quartz in the veins is generally medium to coarse grained, commonly has cockade and(or) comb structure, and is vuggy. The trend of the veins and fracturing is east-northeast to southeast, dipping $60^{\circ}-90^{\circ}$ south-southeast to southwest. The most common and generally the only sulfide mineral in these quartz veins is tetrahedrite, which is commonly weathered and oxidized to malachite, azurite, limonite, and other oxides. Scheelite, also a sparse constituent of these veins, gives rise to low but anomalous values of tungsten in vein samples from this area. The mode of occurrence of scheelite is similar to that in deposits in the Silver Lake district to the north where tungsten has been produced.

\section{Exploration activity}

Little recent exploration has been reported in the wilderness, but some exploration is currently being done on the periphery. Since 1978, a major mining company has been evaluating claims in the Mount Evans-Mount Howe area. In 1980, another company located claims near the Old Dominion mine (fig. 9) on previously worked veins that may extend into the wilderness. Exploration is also being conducted on a silver-bearing quartz vein just north of the wilderness near the Monk claim (fig. 9, no. 33).

\section{Examination of prospects}

During the mineral resource study of the Anaconda-Pintlar wilderness, 40 prospects were examined. Summary descriptions of these are given in table 5. Thirty are in the Moose Lake district, six in the Rainbow Mountain-Storm Lake area, and four isolated prospects lie near the eastern and southwestern borders of the wilderness. Included in the 40 are 10 that are outside the wilderness. These were examined to determine possible extensions of the same or similar mineralized zones or structures into the wilderness.
The classification of resources determined for prospects in the study area follows the guidelines in U.S. Geological Survey Circular 831 (U.S. Bureau of Mines and U.S. Geological Survey, 1980). Identified resources are defined as resources whose location, grade, quality, and quantity are known or estimated from specific geologic evidence. Undiscovered resources are resources the existence of which are postulated from a knowledge of broad geologic controls.

Five deposits in the study area have a total of 180,300 tons of identified resources (table 5) of silver, copper, lead, and minor gold and zinc. Eleven additional prospects (table 5) may warrant further exploration.

Prospects of the Moose Lake district within the wilderness are mostly in the Senate mine-Kelly Lake and Warren Peak areas. Resources at two prospects in the Senate mine-Kelly Lake area total about 91,000 tons. The largest, the Clipper lode (no. 3 on fig. 9), is $5.8 \mathrm{ft}$ thick and along a strike length of $600 \mathrm{ft}$ is inferred to contain 87,000 tons of mineralized rock that averages $1.2 \mathrm{oz}$ of silver per ton and 0.48 percent copper. Two veins in the Warren Peak area contain resources of about 18,300 tons. The largest, at the Luke claims (fig. 9, no. 25), is $2 \mathrm{ft}$ thick and at least $450 \mathrm{ft}$ long; it contains about 17,000 tons averaging $1.4 \mathrm{oz}$ of silver per ton, and 0.54 percent lead. A vein at the Barbara Ann Claim (fig. 5, no. 14) is about $2 \mathrm{ft}$ thick, $860 \mathrm{ft}$ long, and is inferred to contain 71,000 tons averaging $0.02 \mathrm{oz}$ of gold per ton, $4.1 \mathrm{oz}$ of silver per ton, 0.3 percent copper, 0.33 percent lead, and 0.12 percent zinc.

Near Hidden Lake (fig. 9, no. 5) a replacement deposit is indicated by malachite-stained, scheelitebearing float in talus. The talus and few outcrops suggest replacements along calcareous interbeds in quartzite intruded by granodiorite. Samples have as much as 0.08 percent tungsten trioxide $\left(\mathrm{WO}_{3}\right)$ and 0.04 percent copper.

Fissure veins in intrusive rocks occur at seven Warren Peak prospects. Generally less than $1 \mathrm{ft}$ thick, the veins contain scattered molybdenum, chalcopyrite, and pyrite stringers. None is well enough exposed to evaluate resources.

At other prospects in the wilderness, exposures are too poor to determine resources. Nonetheless, on the basis of analyses of samples from the few mineralized rock exposures at the One Hundred Acre Meadow prospect and the Kurt Peak, Rainbow Pass, and Storm Lake occurences, this prospect and these occurrences may warrant further exploration.

\section{ASSESSMENT OF MINERAL RESOURCE POTENTIAL}

The mineral resource evaluation of the Anaconda-Pintlar study area is based on the analysis and synthesis of all available data from studies of geology, geochemistry, geophysics, remote sensing, and prospects of the area. Table 6 lists areas that have mineral resource potential, the degree of resource potential, the kinds of resources (commodities) in each, the types of deposits in each area, and the criteria used in rating the areas. These areas are shown on figure 10. The potential is rated as high, moderate, and low. Where grade, quality, and quantity of ore are known from the investigation of 


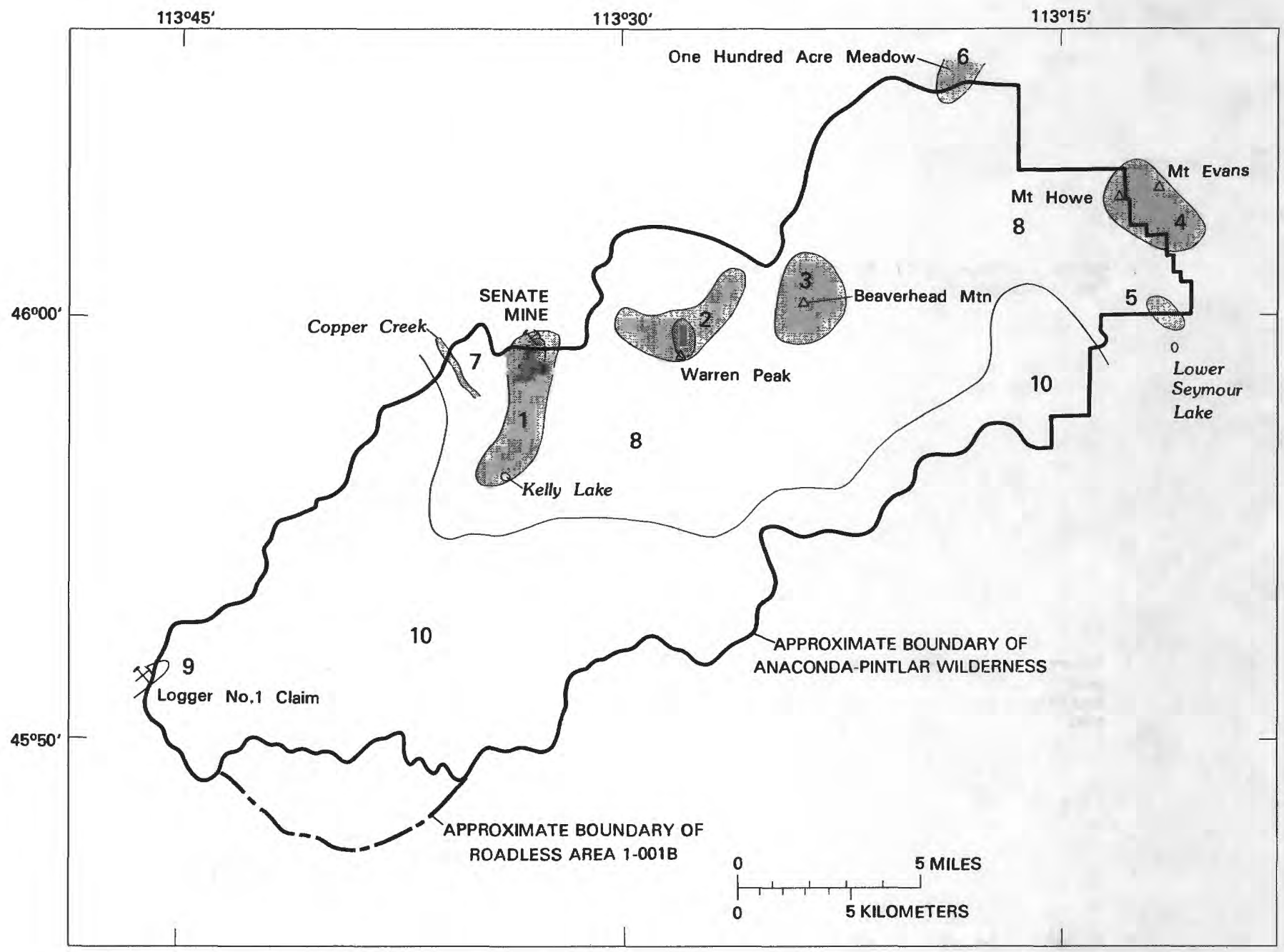

\section{EXPLANATION}

AREA OF MODERATE MINERAL RESOURCE POTENTIAL

AREA OF HIGH MINERAL RESOURCE POTENTIAL

Figure 10.--Mineral resource potential of the Anaconda-Pintlar Wilderness, contiguous roadless area, and vicinity. 
Table 6.--Mineral resource potential of the Anaconda-Pintlar Wilderness Study Area

[Areas are shown on figure 10]

\begin{tabular}{|c|c|c|c|c|c|c|}
\hline & Area $^{1}$ & Potential & $\begin{array}{l}\text { Identifed } \\
\text { resources }\end{array}$ & $\begin{array}{l}\text { Undiscovered } \\
\text { resources }\end{array}$ & $\begin{array}{l}\text { Deposit } \\
\text { types }\end{array}$ & Favorable criteria ${ }^{2}$ \\
\hline & $\begin{array}{l}\text { Senate } \\
\text { mine-Kelly } \\
\text { Lake area. }\end{array}$ & $\begin{array}{l}\text { Moderate to } \\
\text { high. }\end{array}$ & $\mathrm{Ag}, \mathrm{Cu}, \mathrm{Pb}$ & $\underset{A u}{\mathrm{Ag}, \mathrm{Cu}, \mathrm{Pb} \text {, }}$ & $\begin{array}{l}\text { Mesothermal } \\
\text { vein, } \\
\text { replacement, } \\
\text { placer. }\end{array}$ & $\begin{array}{l}\text { 1. Occurrence of known deposits. } \\
\text { 2. Geochemical anomalies in rock } \\
\text { samples: Area of high } \\
\text { potential defined by zone of } \\
\mathrm{Cu}, \mathrm{Ag}, \mathrm{Pb}, \mathrm{Sb}, \mathrm{As}, \mathrm{Mo} \text {, and } \mathrm{W} \\
\text { anomalies; area of moderate } \\
\text { potential by sporadic } \mathrm{As}, \mathrm{Cu} \text {, } \\
\text { and Mo anomalies. } \\
\text { 3. Occurrence of favorable } \\
\text { quartzite unit conducive to } \\
\text { brittle fracture. } \\
\text { 4. Occurrence of favorable } \\
\text { structural zone of highly } \\
\text { fractured rocks. } \\
\text { 5ccurrence of surficial } \\
\text { sedimentary deposits suitable } \\
\text { for placer deposits. }\end{array}$ \\
\hline & $\begin{array}{l}\text { Warren } \\
\text { Peak area. }\end{array}$ & $\begin{array}{l}\text { Moderate to } \\
\text { high. }\end{array}$ & $\mathrm{Ag}, \mathrm{Pb}, \mathrm{Cu}$ & $\begin{array}{l}\mathrm{Ag}, \mathrm{Pb}, \mathrm{Cu}, \\
\mathrm{Zn}, \mathrm{Mo} .\end{array}$ & $\begin{array}{l}\text { Mesothermal } \\
\text { vein, } \\
\text { porphyry, } \\
\text { or stock- } \\
\text { work. }\end{array}$ & $\begin{array}{l}\text { 1. Occurrence of known deposits: } \\
\text { Area of high potential } \\
\text { defined by concentration of } \\
\text { deposits including two with } \\
\text { identified resources; area of } \\
\text { moderate potential by several } \\
\text { prospects and one deposit } \\
\text { with ident if ied resources. } \\
\text { 2. Anomalous tin contents in } \\
\text { rock samples. } \\
\text { 3. Favorable geology cons ist ing } \\
\text { of granodiorite stock } \\
\text { intruded into siliceous and } \\
\text { calcareous sediments. } \\
\text { 4. Area in part coincides with } \\
\text { and flanks area of pos itive } \\
\text { magnetic anomaly. } \\
\text { 5. Occurrence of hydrothermalily } \\
\text { altered rocks indicated by } \\
\text { limonite mapping. }\end{array}$ \\
\hline & $\begin{array}{l}\text { Beaver- } \\
\text { head } \\
\text { Mountain } \\
\text { area. }\end{array}$ & Moderate--- & None-n..... & $\begin{array}{c}\mathrm{Mo}, \mathrm{Cu}, \mathrm{Ag}, \\
\text { W. Sn. }\end{array}$ & $\begin{array}{l}\text { Stockwork or } \\
\text { porphyry, } \\
\text { mesothermal } \\
\text { vein, skarn. }\end{array}$ & $\begin{array}{l}\text { 1. Geochemical anomalies of Mo, } \\
\mathrm{Sn}, \mathrm{W}, \mathrm{Ag}, \mathrm{Zn}, \mathrm{Be}, \mathrm{As}, \mathrm{Sb} \text {, } \\
\mathrm{Cu}, \mathrm{Bi}, \text { and } \mathrm{F} \text { in rock } \\
\text { samples. } \\
\text { 2. Favorable geology consisting } \\
\text { of concentration of quartz } \\
\text { veins with altered envelopes } \\
\text { and altered dikes in } \\
\text { granodiorite. } \\
\text { 3. Area lies on flanks of } \\
\text { negative magnetic anomaly. } \\
\text { 4. Occurrence of hydrothermaily } \\
\text { altered rocks ind icated by } \\
\text { limonite mapping. }\end{array}$ \\
\hline & $\begin{array}{l}\text { Mount } \\
\text { Howe-Mount } \\
\text { Evans area. }\end{array}$ & Moderate--- & None--...-- & Mo, $\mathrm{Cu}-\ldots$ & $\begin{array}{l}\text { Stockwork or } \\
\text { porphyry, } \\
\text { mesothermal } \\
\text { vein. }\end{array}$ & $\begin{array}{l}\text { 1. Geochemical anomalies of } \mathrm{Mo}, \\
\mathrm{Sn}, \mathrm{Be}, \mathrm{Ag}, \mathrm{Cu}, \mathrm{As}, \mathrm{Zn}, \mathrm{W} \text {, } \\
\mathrm{Bi} \text {, and } \mathrm{F} \text { in rock samples. } \\
\text { 2. Favorable geology consisting } \\
\text { of zone of contact } \\
\text { metamorphosed quartz ites and } \\
\text { argillites, concentration } \\
\text { of dikes and quartz veins, } \\
\text { and widespread altered rock. } \\
\text { 3. Area in part coincides with } \\
\text { and flanks a positive magnetic } \\
\text { anomaly. } \\
\text { 4. Widespread and intense } \\
\text { limonite sta in ing due to } \\
\text { hydrothermal alteration. }\end{array}$ \\
\hline & $\begin{array}{l}\text { Lower } \\
\text { Seymour } \\
\text { Lake area. }\end{array}$ & Moderate--- & None---..--- & Mo, Ag, W-- & $\begin{array}{l}\text { Stockwork or } \\
\text { porphyry. }\end{array}$ & $\begin{array}{l}\text { 1. Geochemical anomalies of } \mathrm{Mo} \text {, } \\
\mathrm{Ag}, \mathrm{Bi}, \mathrm{Cu}, \mathrm{Pb}, \mathrm{Sn}, \mathrm{W}, \mathrm{Zn}, \mathrm{F}, \\
\text { and } \mathrm{Be} \text { in rock- and stream- } \\
\text { sediment samples. } \\
\text { 2. Favorable geology consist ing } \\
\text { of strongly altered rock, } \\
\text { limonitic zones, and numerous } \\
\text { veins in granodiorite. } \\
\text { 3. Favorable structures } \\
\text { consist ing of closely spaced } \\
\text { fractures and intensely } \\
\text { sheared rock. } \\
\text { 4. Area is on flank of positive } \\
\text { magnetic anomaly. }\end{array}$ \\
\hline
\end{tabular}


Table 6.--Mineral resource potential of the Anaconda-Pint lar Wilderness Study Area--Cont inued

\begin{tabular}{|c|c|c|c|c|c|}
\hline Area ${ }^{1}$ & Potential & $\begin{array}{l}\text { Ident ifed } \\
\text { resources }\end{array}$ & $\begin{array}{l}\text { Undiscovered } \\
\text { resources }\end{array}$ & $\begin{array}{l}\text { Deposit } \\
\text { types }\end{array}$ & Favorable criteria ${ }^{2}$ \\
\hline $\begin{array}{l}\text { 6. One } \\
\text { Hundred } \\
\text { Acre } \\
\text { Meadow } \\
\text { area. }\end{array}$ & Moderate-.- & None------- & $\mathrm{Ag}, \mathrm{W}, \mathrm{Cu}--$ & $\begin{array}{l}\text { Mesothermal } \\
\text { vein, } \\
\text { replacement } \\
\text { zones. }\end{array}$ & $\begin{array}{l}\text { 1. Occurrence of known deposits. } \\
\text { 2. Occurrence of favorable } \\
\text { Paleozoic carbonate units. } \\
\text { 3. Favorable structural zone of } \\
\text { highly fractured rocks. } \\
\text { 4. Area flanks major positive } \\
\text { magnetic anomaly. }\end{array}$ \\
\hline $\begin{array}{l}\text { 7, Copper } \\
\text { Creek. }\end{array}$ & Moderate--- & None------- & $A u-\ldots \ldots$ & Placer--...- & $\begin{array}{l}\text { 1. Anoma lous gold values in } \\
\text { panned-concentrate samples } \\
\text { from Copper Creek. } \\
\text { 2. Occurrence of stream and } \\
\text { glacial depos its. } \\
\text { 3. Occurrence of metal-bearing } \\
\text { veins upstream in drainage } \\
\text { area. }\end{array}$ \\
\hline $\begin{array}{l}\text { 8. Area } \\
\text { north of } \\
45^{\circ} 55^{\circ} \\
\text { and east } \\
\text { of } 113^{\circ} 36^{\prime} \text {. }\end{array}$ & Low-_....... & None----.-- & $\begin{array}{c}A u,{ }_{M}{ }^{A g}, \mathrm{Cu}, \\
\mathrm{M}_{0},\end{array}$ & $\begin{array}{l}\text { Disseminated } \\
\text { stockwork } \\
\text { or porphry, } \\
\text { skarn, } \\
\text { mesothermal } \\
\text { vein, } \\
\text { replacement } \\
\text { zones. }\end{array}$ & $\begin{array}{l}\text { 1. Occurrence of prospects. } \\
\text { 2. Sporadic geochemical } \\
\text { anomalies for rock and } \\
\text { stream-sediment samples. } \\
\text { 3. Areas of hydrothermal } \\
\text { alteration ind icated by } \\
\text { limonite mapping. } \\
\text { 4. Occurrence of favorable rock } \\
\text { units in contact zones of } \\
\text { intrus ives. } \\
\text { 5. Occurrence of favorable } \\
\text { structural zones of } \\
\text { fracturing. } \\
\text { 6. Presence of favorable } \\
\text { magnet ic anomalies. }\end{array}$ \\
\hline $\begin{array}{l}\text { 9, Logger } \\
\text { No. } 1 \\
\text { claim } \\
\text { area. }\end{array}$ & Low-....... & None--...-- & $\begin{array}{l}\mathrm{Au}, \mathrm{Ag}, \mathrm{Mo} \\
\mathrm{Be} .\end{array}$ & $\begin{array}{l}\text { Mesothermal } \\
\text { vein. }\end{array}$ & $\begin{array}{l}\text { 1. Occurrence of prospect. } \\
\text { 2. Occurrence of zone of } \\
\text { sheared rock. }\end{array}$ \\
\hline $\begin{array}{l}\text { 10, Remainder L } \\
\text { of study } \\
\text { area. }\end{array}$ & Low--- & None--.---.- & Various--.-- & Various---.- & $\begin{array}{l}\text { 1. Occurrence of weak and } \\
\text { sporadic geochemical anomalies } \\
\text { in stream-sed iment samples. }\end{array}$ \\
\hline
\end{tabular}

${ }^{1}$ See section on "Assessment of mineral resource potential" (this report) which includes discussion of each area.

2 See section on "Assessment of mineral resource potential" (this report) for more detail of favorable criteria. 
prospects, resources are listed as identified. Resources the existence of which are postulated on the basis of some combination of geology, geochemistry, geophysics, and remote sensing are listed as undiscovered. The deposit types are based on deposits known to occur in the area or on mineral deposit models that fit the geologic, geochemical, and geophysical characteristics of the area. The favorable criteria used in the rating of potential include

(1) The occurrence of known deposits: the types of deposits and the abundance of prospects.

(2) The occurrence of geochemical anomalies: the elements and their concentration ranges, the media sampled, the proportion of anomalous to background values, and suites of anomalous elements as representatives of particular types of deposits.

(3) Favorable geology: the occurrence of favorable host rocks, favorable structural setting, and the presence of or proximity to igneous rocks as heat or metal sources or as hosts to deposits.

(4) Favorable geophysics: principally the proximity or coincidence of positive and negative magnetic anomalies which, in general, indicate the configuration of intrusive contacts in the subsurface. The areas that occur along the flanks of either a major positive or negative anomaly are the most favorable for the occurrence of deposits.

(5) The occurrence of hydrothermally altered areas as indicated by limonite mapping from Landsat data.

Two areas within the study area have moderate to high potential for resources, five areas have moderate potential, and two have low potential. Undiscovered resources are expected in two principal deposit types: porphyry (or stockwork) and mesothermal vein. Other types that are known or expected to occur are replacement, skarn, disseminated, and placer. Of greatest interest are the porphyry or stockwork deposits, which tend to be large and amenable to large-tonnage, low-unit-cost operations. Vein deposits would be higher in grade but mostly small and narrow and expensive to mine. Known vein deposits in the area all contain low grades of metals.

\section{Area 1: Senate mine-Kelly Lake area}

This area, a north-northeast-trending zone extending from the vicinity of Kelly Lake to the Senate mine, has moderate to high potential for the occurrence of resources of silver, copper, lead, and gold in mesothermal veins, replacement zones, and placers. Geology and structure of this area are similar to that in the previously described Senate mine area. The area of high potential is defined by geochemical anomalies of copper, silver, arsenic, lead, antimony, molybdenum, and tungsten in rock samples. It includes the zone of mineralized rock present at the Senate mine and extends into the wilderness including the Ivanhoe Lake prospects in the wilderness, which have identified resources (table 5). For this area of high potential, many rock samples contain $>2 \mathrm{ppm}$ silver, $\geq 200 \mathrm{ppm}$ copper, $\geq 20 \mathrm{ppm}$ arsenic, $\geq 300 \mathrm{ppm}$ lead, and 21 ppm antimony.

The area of moderate potential extending out from and south of the Senate mine area has sporadic copper, arsenic, silver, and molybdenum concentrations and includes several deposits, one, the Clipper lode, that has identified resources (table 5). The geology and structure are similar to that in the Senate mine area but evidence of mineralizatior is less. Replacement of quartzite by carbonate and sulfate minerals, such as is seen at the Senate mine, is sparse.

Copper and silver are the most valueble resources in area 1. The known deposits, however, are small and narrow and would be expensive to mine. In general the grades are low, commonly less than $1 \mathrm{oz}$ of silver per ton and 1 percent copper. Because metalbearing veins are present at the head of the stream that drains the area of the Senate mine, area 1 also has potential for the occurrence of small placer gold resources in alluvial and glacial deposits along the small stream to the east of the mine that is a tribut ary to the Middle Fork Rock Creek.

\section{Area 2: Warren Peak area}

Numerous small deposits occur in this area including three that have 89,300 tons of identified resources (table 5). These deposits are quartz vein in granodiorite or in quartzite or carbonate rocks adjacent to a granodiorite stock. The area of ligh potential in the center of the Warren Peak area has a higher concentration of veins and includes two deposits, Luke claims and Warren Peak prospect, that have identified resources. The known deposits are small and narrow and would be expensive to mine. Grades, especially of silver ore, tend to be higher than for deposits in area 1, but known deposits are probably marginal. Likewise, any undiscovered resources in vein-type deposits would probably be small, narrow, and $m$ arginal in grade.

The area has moderate to high potential for resources of silver, lead, copper, zinc, and molybdenum in mesothermal vein and porphyry or stockwork deposits. Favorable factors for the occurrence of deposits include the presence of known deposits and favorable geology consisting of a granodiorite stock intrusive into host rocks of Paleozoic and Precambrian age. Factors favorable for the occurrence of porphyry or stockwork deposits include the appropriate age and composition of the stock, the presence of veins, the occurrence of aroas of limonite related to hydrothermal alteration, the occurrence of tin anomalies, and the presence of a positive magnetic anomaly.

\section{Area 3: Beaverhead Mountain area}

At the center of this area, best exposed on ridges north of Beaverhead Mountain, is a mineralized zone that consists of a swarm of narrow quartz veins, accompanied by disseminated pyrite in granodiorite (fig. 6). This granodiorite stock intrudes the Helena and Mount Shields Formations and $a$ biotite monzogranite stock; fewer quartz veins are found in these units than in the granodiorite, but at one locality a contact metamorphic zone of pyrite-bea-ing jasperoid and skarn is developed at the granodioriteHelena contact. Area 3 is also cut by several porphyritic rhyolite dikes, most of which have argillic and sericitic alteration products and contain 
disseminated pyrite. These dikes contain conspicuous smoky quartz phenocrysts. The area also has several conspicuous zones of limonite related to hydrothermal alteration (fig. 3 ).

Quartz veins seem to be of two types based on their thickness and mineralogy, although the two may be related genetically and temporally. The thicker type is $1-18$ in. thick, is commonly coarsely crystalline and locally vuggy, and contains minor pyrite and chalcopyrite(?) (mostly altered), some muscovite, and rare beryl. These veins are subparallel and form an east-northeast-trending swarm. The second set of narrow veins is present as an intersecting network of 0.1 - to 0.5-inch-thick veinlets that contain only quartz. Vein-related alteration developed minor disseminated pyrite and muscovite adjacent to the veins.

The area has a strong multi-element geochemical signature based on trace-element data for rock samples (table 2). Elements that occur in anomalous concentrations in the greatest number of samples include tin, molybdenum, copper, and silver. Elem ents that also occur in anomalous amounts, but with less frequency, are arsenic, antimony, zinc, tungsten, beryllium, bismuth, and fluorine. The complexity of the trace-element geochemistry suggests that the area has been subjected to two or more pulses of hydrothermal activity.

Although the intensity of alteration is low, several factors indicate a moderate potential for the occurrence of resources of molybdenum, copper, silver, tungsten, and possibly tin in a porphyry or stockwork deposit in the Beaverhead Mountain area. Favorable geology-a stock of appropriate age and composition, evidence of multiple intrusive activity, and presence of veins and altered rock--and a geochemical suite of molybdenum, copper, tin, tungsten, and beryllium are favorable criteria in this area. The area also has potential for resources of tungsten, molybdenum, and copper in skarn deposits along the granodiorite (TKgd)-Helena contact and for resources of silver and copper in mesothermal veins. The geochemistry, altered rocks, and reins suggest a mineralizing process peripheral to a porphyry system and that any porphyry deposit formed would likely be at a depth of more than several hundred feet below the present surface.

\section{Area 4: Mount Howe-Mount Evans area}

This is an area of complex geology where quartzite and argillite of the Mount Shields Formation have been intruded and metamorphosed by stocks of quartz diorite, monzogranite, and granodiorite and a multitude of granodiorite porphyry, dacite porphyry, diorite, and aplite dikes (fig. 7). Evidence of mineralization includes the occurrence of quartz veins, very strong limonitic alteration of the metasedimentary rocks, and moderate alteration of some of the dikes. Some of the quart $z$ veins, mostly in the vicinity of Mount Howe, have molybdenite and ferrimolybdite. The limonitic alteration was very intense and widespread (fig. 3) and was due to the oxidation of pyrite that occurs disseminated in quartzite and mica schist of the contact metamorphosed zone. The pyrite and associated limonite are most abundant in a north- to northwest- trending zone along both sides and parallel to a diorite dike that crops out to the west of Mount Evans.

Rock samples from the area have trace-element anomalies of silver, tin, beryllium, copper, amsenic, zinc, molybdenum, bismuth, and fluorine (tabl: 3), a suite similar to that in the Beaverhead Mountair area.

Like the Beaverhead Mountain area, this area has moderate potential for the occurrence of resou"ces of molybdenum and copper in stockwork or porphyry and mesothermal vein deposits. In addition to the favorable geology and geochemistry, the area in part coincides with and flanks a very prominent fositive magnetic anomaly. Part of this anomaly is associated with exposures of a quartz diorite intrusive ccmplex, and in the area of Mount Howe and Mount Evans the magnetic anomaly probably reflects the subrurface configuration of this intrusive complex.

\section{Area 5: Lower Seymour Lake area}

This area has moderate potential fnr the

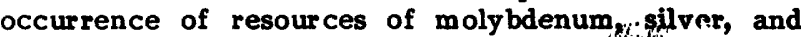
tungsten in stockwork or porphyry depomiss Although this area is poorly exposed and smalletith size than areas 3 and 4, the intensity of alteration ard vein emplacement was greater here. An exposed mineralized zone in altered, sheared granodicmite is adjacent to and partly in the wilderness, but it areal extent cannot be determined because it is term inated by a fault on the southeast side and is covered on the other sides by surficial deposits (fig. 8). Evidence of mineralization includes silicically, sericiticall", and argillically altered rocks, moderate to strong limonite staining, and the occurrence of quartz veins as thick as 12 in. and containing limonite after pyrite and ferrimolybdite after molybdenite. Fluorite was also recognized in thin quartz veinlets.

Rock and stream-sediment samples show anomalous concentrations of molybdenum, silver, bismuth, copper, lead, tin, tungsten, zinc, and fl *orine, (table 4)--a geochemical suite similar to that in areas 3 and 4 and compatible with the occurrenc: of a porphyry or stockwork molybdenum or copper deposit. The area also flanks a major positive magnetic anomaly that lies to the southeast.

\section{Area 6: One Hundred Acre Meadow area}

This area, which straddles the wilderness boundary, has moderate potential for the occrrrence of resources of silver, tungsten, and cop-er in mesothermal vein and replacement deposits similar to those in the Silver Lake district to the nortb. The rocks consist of Paleozoic units, mostly carbonate beds, that are folded and faulted and cut by sparse narrow quartz veins that locally contain sulfides. Two known deposits are included in the area; there are small, but larger replacement deposits con'aining higher grades of tungsten and silver may occur in the subsurface. This area lies close to a major positive magnetic anomaly.

\section{Area 7: Copper Creek area}

This area lies along the valley of the uppor part of Copper Creek that drains part of the Senate mineKelly Lake mineralized zone, and it has moterate 
potential for the occurrence of small placer gold deposits in alluvial and glacial deposits along Copper Creek. Several panned-concentrate samples from the stream in the wilderness and just to the north of the boundary contain anomalous concentrations of gold, which may have come from vein deposits that were eroded higher in the drainage basin in the Senate mineKelly Lake area.

\section{Area 8}

This is a large area north of $45^{\circ} 55^{\prime}$ and east of $113^{\circ} 36^{\prime}$ that surrounds areas 1 through 7 . Throughout this area is scattered and weak evidence suggesting low potential for undiscovered resources of gold, silver, copper, molybdenum, and tungsten. Evidence includes the occurrence of a few prospects, sporadic geochemical anomalies in rock and stream-sediment samples, and small areas of limonite related to hydrothermal alteration. Geology and structure are generally favorable for the occurrence of various types of deposits, and several positive and one negative favorable magnetic anomalies are present.

\section{Area 9}

This is a small area including the Logger No. 1 claim. Samples from this prospect have anomalous amounts of gold, silver, molybdenum, and beryllium. This area includes a zone of shearing and has low potential for resources of the above commodities.

\section{Area 10}

This area includes all of the remaining parts of the wilderness and contiguous roadless area that are not in areas 1-9. Except for the occurrence of weak and sporadic geochemical anomalies in streamsediment samples, this area lacks, in general, evidence of hydrothermal alteration and mineralization. Geology, geophysics, and structure are less favorable than in areas 1 through 9. This area has low potential for undiscovered resources of metallic minerals.

\section{Potential for nonmetallic and energy resources}

Workable deposits of sand, gravel, or stone may occur in the study area, but these materials are more readily accessible in other areas outside the wilderness and contiguous roadless area. There is no evidence of potential for geothermal, coal, oil, or gas resources. There are no krown hot springs or young volcanic rocks in the area, and coal-bearing sediment ary rocks do not occur. Oil and gas may be present in the Paleozoic sedimentary rocks of the study area at depth, but due to the lack of subsurface and seismic data the potential for resources of oil and gas cannot be fully assessed. However, plutonic rocks of Cretaceous to Tertiary age are exposed over much of the study area, and geophysical surveys indicate the presence of plutonic rocks in much of the subsurface in and adjacent to the study area. This suggests that the region has been subjected to temperatures high enough to destroy any significant deposits of oil or gas that may have formed in the sedimentary rocks.

\section{REFERENCES CITED}

Almond, H., 1953, Field method for determinatinn of traces of arsenic in soils: Analytical Chemistry, v. 25, p. 1766-1767.

Close, T. J., Federspiel, F. E., Causey, J. D., Willett, S. L., Morris, R. W., and Huffsmith, J. R., 1982, Mineral resources of the Anaconda-P'ntlar Wilderness, Beaverhead, Deer Lodge, Granite, and Ravalli Counties, Montana: U.S. Bureau of Mines MLA Open-File Report 24-82, 17 p.

Corry, A. V., 1920, Senate group of lode claims, Granite County, Montana: Unpublished data on file in office of U.S. Bureau of Mines, Spokane, Wash., 12 p.

Emmons, W. H., and Calkins, F. C., 1913, Geology and ore deposits of the Philipsburg quadrangle, Montana: U.S. Geological Survey Professional Paper 78, 271 p.

Flood, R. E., 1974, Structural geology of the upper Fishtrap Creek area, central Anaconda Range, Montana: Missoula, Montana University, unpublished M. A. thesis, 71 p.

1975, Relationship of igneous emplacement to deformational history in the Anaconda Range, Montana: Northwest Geology, v. 4, p. 9-14.

Grimes, D. J., and Marranzino, A. P., 1968, I"rect current arc and alternating-current spark emission spectrographic field methods fo* the semiquantitative analysis of geologic matemials: U.S. Geological Survey Circular 591, 6 p.

Harrison, J. E., Griggs, A. B., and Wells, J. D., 1974, Tectonic features of the Precambrian Belt basin and their influence on post-Belt structures: U.S. Geological Survey Professional Paper 866, 15 p.

Mutschler, F. E., Wright, E. G., Ludington, Steve, and Abbott, J. T., 1981, Granite molybdenite systems: Economic Geology, v. 76, p. 874-897.

Oster, T. W., 1944, Senate Mine, Granite Ccrunty, Montana: Unpublished data on file in of fice of U.S. Bureau of Mines War Minerals Report. U.S. Bureau of Mines, Spokane, Wash., 6 p.

Pederson, R. J., 1976, Geology of the upper Rock Creek drainage, Granite County, Mor'ana: Butte, Montana College of Mineral Scienc? and Technology, unpublished M. S. thesis, 238 p.

Podwysocki, M. H., Segal, D. B., and Houser, S. S., 1980 , Digital mapping of limonitic rocks using Landsat MSS ratioed data abs.: $P$ :cora Symposium, 6th Annual, Sioux Falls, South Dakota, Program with Abstracts, p. 49-50.

Pohn, H. A., 1976, Copper exploration research in Iran, in Fary, R. W., ed., CENTO workshop on applications of remote sensing data and methods, October 5-12, 1976, Instanbul, Turkey, Proceedings: p. 152-169.

Poulter, G. J., 1956, Map of Georgetown thrust area, Granite and Deer Lodge Counties, Mortana: Montana Bureau of Mines and Geology Geolngical Investigation Map 1, scale 1:48,000.

Rowan, L. C., and Abrams, M. J., 1978, Evaluation of Landsat multispectral scanner images for mapping altered rocks in the East Mintic Mountains, Utah: U.S. Geological Survey OpenFile Report 78-736, 73 p. 
Rowan, L. C., Goetz, A. F. H., and Ashley, R. P., 1977, Discrimination of hydrothermally altered and unaltered rocks in visible and near-infrared multispectral images: Geophysics, v. 42 , no. 3 , p. 522-535.

Rowan, L. C., Wetlaufer, P H., Goetz, A.F.H., Billingsley, F. C., and Stewart, J. H., 1974, Discrimination of rock types and detection of hydrothermally altered areas in south-central Nevada by the use of computer-enhanced ERTS images: U.S. Geological Survey Professional Paper 883, 35 p.

Ruppel, E. T., O'Neill, J. M., and Lopez, David, 1982, Slides showing a preliminary geologic map of the Dillon $1^{\circ} \times 2^{\circ}$ quadrangle, Montana and Idaho: U.S. Geological Survey Open-File Report 82-667, slides.

Ruppel, E. T., Wallace, C. A., Schmidt, R. G., and Lopez, D. A., 1981, Preliminary interpretation of the thrust belt in southwest and west-central Montana and east-central Idaho: Montana Geological Society Field Conference and Symposium, p. 139-160.

Sawatzky, D. L., and Raines, G. L., 1978, Geologic uses of linear feature maps derived from smallscale images, in O'Leary, D. W., and Earle, J. L., eds.: Third International Conference on Basement Tectonics Proceedings, Durango, Colo., May 15-19, 1978, p. 91-100.

Segal, D. B., 1983, Use of Landsat multispectral scanner data for the definition of limonitic exposures in heavily vegetated areas: Economic Geology, v. 78, no. 4, p. 711-722.

Siegel, B. S., and Goetz, A.F.H., 1977, Effect of vegetation on rock and soil type discrimination: Photogrammetric Engineering and Remote Sensing, v. 43, no. 2, p. 191-196.

Siems, D. F., Welsch, E. P., and Zimbelman, D. R., 1982, Chemical analyses of minus -200 mesh stream sediments of the Anaconda-Pintlar Wilderness, Beaverhead, Deer Lodge, Granite, and Ravalli Counties, Montana: U.S. Geological Survey Open-File Report 82-490, 25 p.
Stentz, J. C., 1975, Mineral and metal resources of Upper Rock Creek Planning Unit, Deerlodge National Forest: Unpublished data on file at U.S. Forest Service Office, Butte, Mont., 29 p.

U.S. Bureau of Mines and U.S. Geological Survey, 1980, Principles of a resource/reserve classificition for minerals: U.S. Geological Survey Cirinlar 831,5 p.

Walker, D. D., 1960, Tungsten resources of Montana-Deposits of the Philipsburg batholith, Granite and Deer Lodge Counties: U.S. Bureau of M'ines Report of Investigations $5612,55 \mathrm{p}$.

Wallace, C. A., Lidke, D. J., Elliott, J. E., Antweiler, J. C., Campbell, W. L., Hassemer, J. H., Hanna, W. F., Bannister, D. P., and Close, T. J., 1984, Mineral resource potential map of the Sapphire Wilderness Study Area and contiguous roatless areas, Granite and Ravalli Counties, Montana: U.S. Geological Survey Miscellaneous Field Studies Map MF-1469-B, scale 1:50,000.

Ward, F. N., Nakagawa, H. M., Harms, T. F., and Van Sickle, G. H., 1969, A tomic absorption methods of analysis useful in geochemical exploration: U.S. Geological Survey Bulletin 1289, p. 20-22.

Welsch, E. P., and Chao, T. T., 1975, Determination of trace amounts of antimony in geologic matemials by atomic absorption spectrometry: Analytica Chimica Acta, v. 76, p. 65-69.

Welsch, E. P., Siems, D. F., and Zimbelman, D. R., 1983, Geochemical analyses of rocks of the Anaconda-Pintlar Wilderness, Beaverhead, Deer Lodge, Granite, and Ravalli Counties, Montana: U.S. Geological Survey Open-File Report 83-903, 4 p.

Wiswall, C. G., 1976, Structural styles of the southern border of the Sapphire Tectonic Block, Anaconda-Pintlar Wilderness Area, Montana: Missoula, Montana University, unpublished M.A. thesis, 55 p.

1977, Structural styles and the sequenc? of deformation related to the Sapphire Tectonic Block: Northwest Geology, v. 6-2, p. 51-59. 
' 